\title{
Histaminergic Mechanisms for Modulation of Memory Systems
}

\author{
Cristiano André Köhler, ${ }^{1,2}$ Weber Cláudio da Silva, ${ }^{1,3}$ Fernando Benetti, ${ }^{2}$ \\ and Juliana Sartori Bonini ${ }^{2,3}$ \\ ${ }^{1}$ Programa de Pós-Graduação em Ciências Médicas, Faculdade de Medicina, Universidade Federal do Rio Grande do Sul, \\ Ramiro Barcelos 2400, 90035-903 Porto Alegre, RS, Brazil \\ ${ }^{2}$ Centro de Memória, Instituto do Cérebro, Pontifícia Universidade Católica do Rio Grande do Sul, Ipiranga 6690, 90610-000 Porto \\ Alegre, RS, Brazil \\ ${ }^{3}$ Departamento de Farmácia, Universidade Estadual do Centro Oeste, Simeão Camargo de Sá 03, 85040-080 Guarapuava, PR, Brazil
}

Correspondence should be addressed to Juliana Sartori Bonini, juliana.bonini@gmail.com

Received 16 March 2011; Accepted 29 June 2011

Academic Editor: Anja Gundlfinger

Copyright (C) 2011 Cristiano André Köhler et al. This is an open access article distributed under the Creative Commons Attribution License, which permits unrestricted use, distribution, and reproduction in any medium, provided the original work is properly cited.

\begin{abstract}
Encoding for several memory types requires neural changes and the activity of distinct regions across the brain. These areas receive broad projections originating in nuclei located in the brainstem which are capable of modulating the activity of a particular area. The histaminergic system is one of the major modulatory systems, and it regulates basic homeostatic and higher functions including arousal, circadian, and feeding rhythms, and cognition. There is now evidence that histamine can modulate learning in different types of behavioral tasks, but the exact course of modulation and its mechanisms are controversial. In the present paper we review the involvement of the histaminergic system and the effects histaminergic receptor agonists/antagonists have on the performance of tasks associated with the main memory types as well as evidence provided by studies with knockout models. Thus, we aim to summarize the possible effects histamine has on modulation of circuits involved in memory formation.
\end{abstract}

\section{Introduction}

The initial step in the formation of a new memory is the acquisition of information related to that particular trace, coming from external stimuli (sensory input arising from subject-environment interaction) or from internal representations (cognition and emotion) [1-5]. This acquisition phase is referred to as learning. After the subject learns, information must be stored either for a brief or a long period of time. While that information remains stored, it can be accessed by the process known as retrieval. Memory, thus comprises the processes responsible for retention and retrieval of learned experience $[5,6]$. Short-term memory retention (defined in minutes or hours) may be converted to long-term retention (defined in days, weeks, or even years) by a specific sequence of events called consolidation which starts immediately after the acquisition phase [1,3-7]. Finally, as time passes, even the most consolidated memories may disappear, a process called forgetting [8].
Not all information reaching the central nervous system (CNS) is stored. Most inputs do not pass the acquisition phase, because they are filtered out by attentional and emotional mechanisms [1, 7-9]. Only a few inputs selected for acquisition and retention are consolidated in longterm memories, and many of the latter are forgotten. Only memories relevant for cognition, emotionally more salient, more focused by attention or associated to stronger sensory input will actually persist. In this context, forgetting may also be seen as a filter, since it only affects memories previously selected to persist by emotional and attentional filters. Thus, the brain systems responsible for learning and memory have a mechanism for preventing information overload $[5,8,10]$.

Most CNS functions may be modulated so as to be activated or deactivated, accelerated or slowed down, and enhanced or diminished, but the exact course of action is determined by the needs relevant for a particular moment [10]. Memory is no exception to this rule and can thus be modulated by experiences occurring about the time when 
it is learned, consolidated, or retrieved [7]. The major modulatory systems are composed of diffusely spread fiber bundles that reach a broad area in the CNS. These fibers originate from nuclei in the brainstem, diencephalon, and basal forebrain. They act by means of several neurotransmitters, including acetylcholine, noradrenaline, dopamine, serotonin, and histamine $[7,11-13]$.

Histamine is involved in the control of several behavioral and neurobiological functions such as the sleep-wake cycle, water intake, motor activity, and nociception [13, 14]. Histamine is known to decrease calcium-dependent membrane conductance in the hippocampus [15], to increase neuronal excitability [16], and control high-frequency oscillations [17, 18 , and it also facilitates NMDA glutamatergic receptormediated responses [19]. However, the part histaminergic circuits play in mnemonic systems is complex. Histamine seems to have different effects in distinct brain regions and may have modulatory effects that differ according to memory type. The evidence indicating the exact role of histamine in learning processes and memory consolidation is still controversial. In particular, the action of the receptor subtypes and how they affect key circuits related to a specific memory system is not well understood.

Here, we will first present a short review of the anatomy, biochemistry, and physiology of the histaminergic system and synaptic plasticity. Then, we will summarize pharmacological studies and other evidence that aims to identify the possible role of histamine in the modulation of brain regions pertaining to circuits involved in processing several types of memories.

\section{Anatomy of the Histaminergic System}

Here, we highlight the key aspects of the anatomy of the histaminergic system. For more details, the reader is encouraged to see [20-23]. Figure 1 presents the main projections of histaminergic neurons in the rat brain.

In vertebrates, neurons that produce histamine are located in the tuberomammillary nucleus (TMN), which is part of the posterior hypothalamus $[14,21]$. The main afferent projections to the TMN come from the infralimbic cortex, lateral septum, preoptical nucleus, and neuronal groups in the brainstem $[23,24]$.

The final target of histaminergic fibers varies slightly across species, but they reach almost the entire CNS. There are moderate-to-dense histaminergic nerve terminals in the cerebral cortex, amygdala, substantia nigra, striatum, hippocampus, and thalamus [20-22]. As a result of these broad projections, histamine receptors are distributed widely in the CNS.

\section{Histamine Metabolism and Neuronal Turnover}

In neurons, histamine is synthesized from the amino acid Lhistidine, which is transported from the extracellular into the intracellular space by the L-aminoacid transporter located in the cell membrane. Once in the cytoplasm, L-histidine is decarboxylated by the enzyme histidine decarboxylase, with histamine as the end product of the reaction. This newly synthesized histamine is transported into synaptic vesicles by the vesicular monoamine transporter 2 (VMAT-2). Action potentials that reach the axonal endings trigger the fusion of the vesicles with the presynaptic membrane, releasing histamine in the synaptic cleft $[13,14]$.

In the extracellular space, histamine is methylated by enzyme histamine methyltransferase in the postsynaptic membrane and glial cells. The end product of this methylation reaction is telemethylhistamine, a metabolite that has no histaminergic activity. Since this amine does not have a high-affinity reuptake mechanism, methylation is the main mechanism for inactivation of released histamine [13, 14]. The turnover rate of neuronal histamine is high, and its half-life (which is about 30 minutes in basal conditions) can change rapidly in response to neuronal activity. Turnover rate increases when subjects experience stressful events such as forced immobilization or a foot shock [21].

The control of histamine synthesis and release is mediated by $\mathrm{H} 3$ type autoreceptors that are located in the soma and axonal endings of the histaminergic neurons [25]. Histamine release may also be regulated by inhibitory M1 muscarinic receptors [25-27], $\alpha 2$ adrenergic receptors $[26,28,29], 5$-HT1A serotonergic receptors [30], $\kappa$ opioid receptors [26, 31] and galanin receptors [26], or facilitatory $\mu$ opioid receptors [32]. In vivo experiments have shown nitric oxide to inhibit histamine release in the hypothalamus [33].

The circadian rhythm of histamine release coincides with changes in the firing pattern of histaminergic neurons occurring during the sleep-wake cycle $[14,33]$. TMN histaminergic neurons resemble a pacemaker activity pattern: they fire action potentials at a slow frequency $(<3 \mathrm{~Hz})$. Electrophysiological recordings of these neurons in cats showed their activity increased during wake time, and decreased or was completely absent during sleep $[14,34,35]$. However, histamine release can follow a faster ultradian rhythm correlated to the delta and theta bands in electroencephalographic recordings $[14,36]$.

\section{Histaminergic Receptors}

In the nervous system of vertebrates most histaminergic axonal endings (varicosities) are not in close contact with postsynaptic sites [37]. This causes histamine to have a diffuse action pattern which is similar to other biogenic amines [14].

To date, histamine effects are known to be mediated by four distinct types of receptors (H1 to $\mathrm{H} 4$ ) coupled to $\mathrm{G}$ proteins and several associated second messengers. Figure 1 shows their distribution across the rat brain. H1, H2, and $\mathrm{H} 3$ receptor types are expressed mainly in nervous tissues, and $\mathrm{H} 4$ type in peripheral tissues like bone marrow and leukocytes. Generally, $\mathrm{H} 1$ and $\mathrm{H} 2$ receptors excite or potentiate excitatory impulses [14, 37-39], while $\mathrm{H} 3$ activation mediates autoinhibition of TMN neurons and inhibits the synthesis and release of histamine or other neurotransmitters 


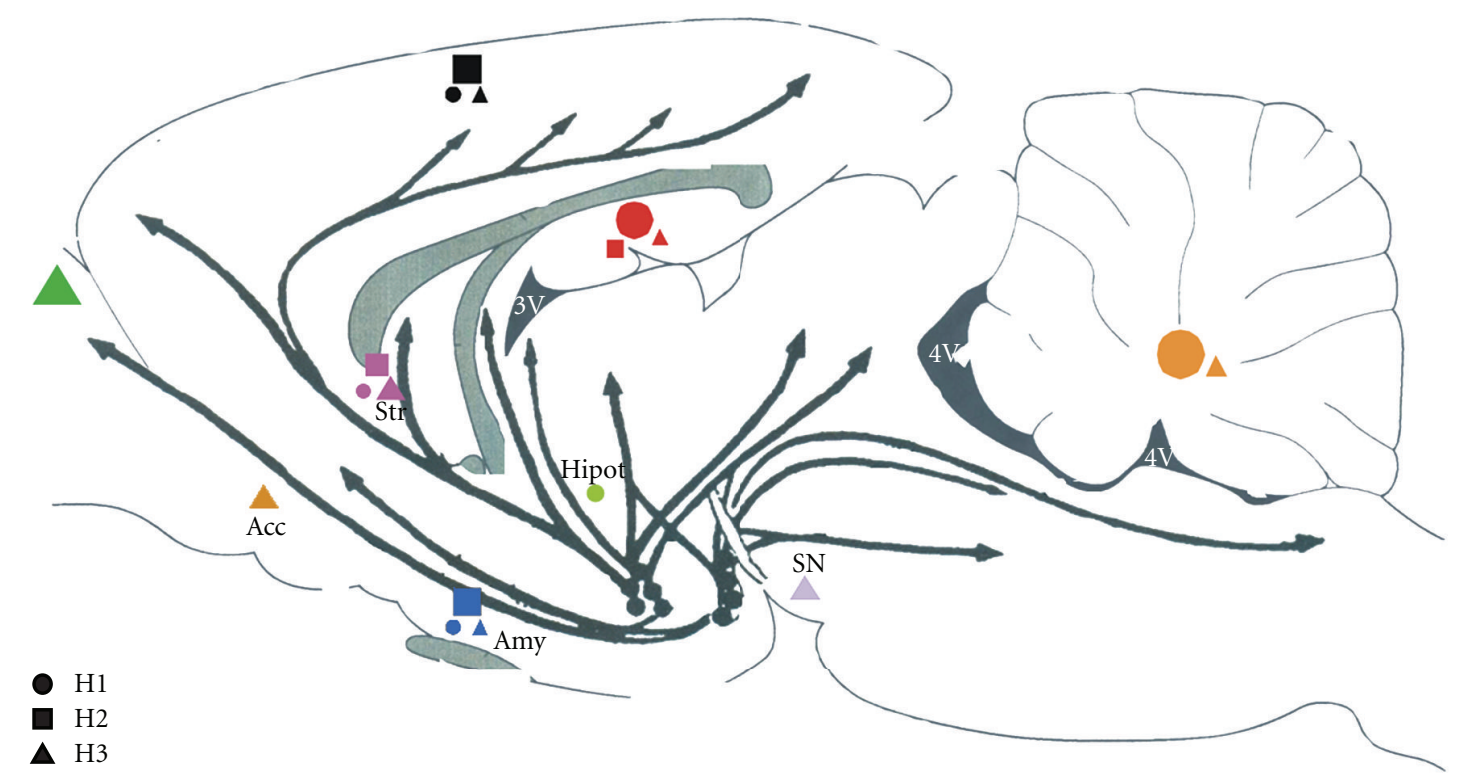

FIGURE 1: Main histaminergic projections and histamine receptor distribution in the rat brain. The shapes mark the main sites where each receptor subtype is located. In areas that have more than one receptor subtype, the shape with the biggest size indicates which is predominant. Acc: nucleus accumbens; Amy: amygdala, Hipot: hypothalamus, Str: striatum, SN: substantia nigra.

such as glutamate, acetylcholine, and noradrenaline [14, 40, 41].

The H1 receptor is a protein with 486-491 amino acid residues and is encoded by a gene without introns [14, 42]. It is coupled to the activation of the $G_{q / 11}$ protein, which activates phospholipase C (PLC) [13]. Thus, the intracellular effects of $\mathrm{H} 1$ receptor activation are mediated by lipid second messengers related to intracellular calcium stores. Downstream signaling pathways are involved in synaptic plasticity. This receptor has been identified in the cortex, hippocampus, amygdala, hypothalamus, thalamus, striatum, and cerebellum [43].

The $\mathrm{H} 2$ receptor is also encoded by a gene without introns and is a protein with 358-359 amino acid residues $[14,44,45]$. It is coupled to the $G_{s}$ protein, which stimulates adenylate cyclase and, subsequently, protein kinase A (PKA) [13]. This receptor is mainly found in the basal ganglia, amygdala, hippocampus, and cortex. $\mathrm{H} 2$ receptor activation also provokes downstream signaling cascades, which are able to mediate functional and structural changes in synapses, as in the case of the PKA pathway [46].

The $\mathrm{H} 3$ receptor has several isoforms $[47,48]$ and is a protein with 326-445 amino acid residues. The isoforms originate in the expression of a single gene through the alternative processing of mRNA (splicing). The intracellular effects of this receptor start with the activation of the inhibitory $\mathrm{G}_{i} / \mathrm{G}_{o}$ protein and the subsequent inhibition of adenylate cyclase [13]. The H3 receptor is found in histaminergic neurons as an autoreceptor, and its intracellular inhibitory actions control histamine synthesis and release $[25,49-51]$. This receptor subtype can also regulate the release of acetylcholine, dopamine, GABA, glutamate, noradrenaline, $5-\mathrm{HT}$, and tachykinins by means of this presynaptic mechanism [14, 40, 41, 52-54]. The H3 receptor also participates in the activation of the MAPK signaling pathway [48]. Its mRNA is found in several types of neurons and has been identified in rats mainly the cerebral cortex, the hippocampus, tenia tecta, nucleus accumbens, caudate putamen, thalamus, amygdala, cerebellum, vestibular nuclei, and some hypothalamic nuclei [55]. The actual location of the receptor protein may be very distant from the cell bodies that express mRNA, and the major brain sites where binding activity takes place are the cerebral cortex, amygdala, nucleus accumbens, caudate putamen, globus pallidus, and substantia nigra [55].

\section{Histamine and Synaptic Plasticity}

Long-term potentiation (LTP) is considered the main demonstration of synaptic plasticity. It was first described in the hippocampus, a brain region directly involved in the formation of several memory types [10, 56-58]. It consists of the lasting enhancement of the postsynaptic response following a high-frequency afferent stimulation. This is seen as an increase in the excitatory postsynaptic potential evoked by a single stimulation pulse when compared to the response evoked before the high-frequency stimulation [57]. There is evidence that this form of synaptic enhancement is also present in other regions of the cerebral cortex, especially during early developmental stages [59]. LTP has several characteristics that make it a strong candidate for the cellular mechanism responsible for long-term memory storage (see [59] for a more detailed review about this matter).

Among the several mechanisms that are jointly responsible for LTP, the activation of the glutamatergic NMDA receptor plays a central role in both the induction and 
maintenance of most LTP types [59]. The calcium influx in the postsynaptic dendritic spine leads to the activation of several signaling cascades, notably the calcium/calmodulindependent protein kinase II (CaMKII), the protein kinase A (PKA), the protein kinase $\mathrm{C}$ (PKC), and the mitogenactivated protein kinase (MAPK). Their final course of action is the activation of transcription factors like CREB, which control the synthesis of the proteins required for the maintenance of the increased postsynaptic response [59-62].

This process may be modulated by histamine [63] LTP was facilitated by histamine in the CA1 area of rat hippocampal slices, since it could be induced with a weak tetanic stimulation when histamine was added to the bath, and this effect persisted even in the presence of $\mathrm{H} 1$ and $\mathrm{H} 2$ receptor antagonists. It was then demonstrated that histamine or its major metabolite, 1-methylhistamine [64], may enhance NMDA induced response and subsequently hippocampal LTP by means of direct channel activation by binding to the polyamine site $[14,65,66]$.

Regarding the effects of histamine on LTP, H1 receptor activation has been shown to reduce the blockage of the NMDA receptor channel mediated by the ion $\mathrm{Mg}^{2+}$, by activating $\mathrm{PKC}$, which leads to increased activation of the glutamatergic receptor [67]. In addition, as already pointed out, histamine can also directly activate the NMDA receptor by binding to the polyamine modulatory site present in this receptor $[19,68]$. Binding is $\mathrm{pH}$ sensitive and is restricted to the NR1/NR2B subunits of the NMDA receptor [64]. Furthermore, $\mathrm{H} 1$ receptor activation leads to the synthesis of postsynaptic retrograde messengers, such as nitric oxide and arachidonic acid, which might be responsible for presynaptic modifications that occur after LTP induction [14, 41]. As an example of the possible involvement of this receptor in LTP, $\mathrm{H} 1$ receptor knockout mice showed impaired LTP induction in the CA1 region of the hippocampus [68].

As mentioned above, the $\mathrm{H} 2$ receptor is a potent stimulator of the cAMP signaling pathway, which is necessary for the late phase of NMDA receptor-dependent LTP [69] and for LTP expression in giant hippocampal mossy fiber synapses [70]. H2 receptors can also increase ionic currents generated by the activation of the NMDA receptor, through blockage of calcium-dependent potassium channels [71], and possibly by mediating the phosphorylation of the NMDA receptor itself by PKA [72]. LTP induction in the hippocampus was also impaired in $\mathrm{H} 2$ receptor knockout mice [68].

The effects might change across different brain regions. $\mathrm{H} 3$ receptors can reduce the release of several neurotransmitters, including glutamate, which might affect synaptic plasticity in hippocampus and striatum $[40,73]$. In dentate gyrus, for instance, $\mathrm{H} 3$ receptor activation hinders synaptic transmission and reduces paired-pulsed facilitation, which is a short-term form of synaptic plasticity [74]. In the CA3 region of the hippocampus, histamine promotes synchronized bursts of action potentials [75], an activity pattern that is known to be a physiological stimulus for the occurrence of LTP in the CA1 region [76]. In the CA1 region, when $\mathrm{Ca}^{2+}$ levels are low and $\mathrm{Mg}^{2+}$ levels are high, histamine causes a lasting potentiation of neuronal excitability, which is mediated mainly by $\mathrm{H} 2$ receptor activation and the PKA signaling pathway, with $\mathrm{H} 1$ and NMDA receptors having a modulatory role in that downstream cascade.

Thus, histamine can enhance LTP through at least three different mechanisms: $\mathrm{H} 1$ receptors favor LTP by increasing intracellular levels of $\mathrm{Ca}^{2+}$ and subsequent PKC activation, both required for LTP induction, the effects of the $\mathrm{H} 2$ receptors are mediated by $\mathrm{cAMP} / \mathrm{PKA}$ signaling pathway activation, which is involved in the maintenance of LTP, and finally, the NMDA receptor can be directly activated by histamine binding to the polyamine site, which can modulate both LTP induction and maintenance $[14,65,66]$.

\section{Histamine and Memory}

6.1. Systemic Administration of Histamine and Memory Performance. The first approach to elucidate the possible role of histamine on memory systems consisted in the systemic administration of several drugs that mimic or counteract the action of histamine and its receptors. These studies are summarized in Table 1.

6.1.1. Memory Impairment. There is a considerable body of work on the role of histamine in models of memory impairment induced by systemic administration of antagonists of the neurotransmitters acetylcholine and glutamate, most notably using the muscarinic receptor antagonist scopolamine or the NMDA receptor antagonist MK-801. The reversal of memory deficit produced by systemic administration of histamine in these models of memory impairment was evaluated in several behavioral tasks (see Table 1 for references).

The evidence suggests that this reversal comes about as a result of the interplay between the histaminergic and cholinergic systems. It is known that both cholinergic and gabaergic projections of the septum to the hippocampus are important in generating hippocampal theta rhythm [100, 101]. It has been demonstrated that histamine can activate gabaergic neurons in the septohippocampal pathway, by binding to the $\mathrm{H} 1$ and $\mathrm{H} 2$ receptors [102]. Furthermore, electrical stimulation of TMN has been shown to increase acetylcholine $(\mathrm{ACh})$ release in the hippocampus [103], and intraseptal infusions of histamine also enhance hippocampal ACh release [104]. Thus, histamine can regulate the hippocampal electrical activity and induce ACh release in the hippocampus in physiological states. The improvement seen in scopolamine-induced deficits might be mediated by such modulation of the septohippocampal pathway.

6.1.2. Physiological Context. Systemic studies that investigate the impact histamine has on memory in a physiological context show the effect to differ with respect to the behavioral paradigm, and thus the memory type, and most studies, deals with the direct manipulation of a single histamine receptor (Table 1).

In aversive tasks like inhibitory avoidance, the systemic administration of an $\mathrm{H} 3$ receptor antagonist improves performance (see Table 1 for references). These studies have used ligands with varying degrees of potency, bioavailability, 


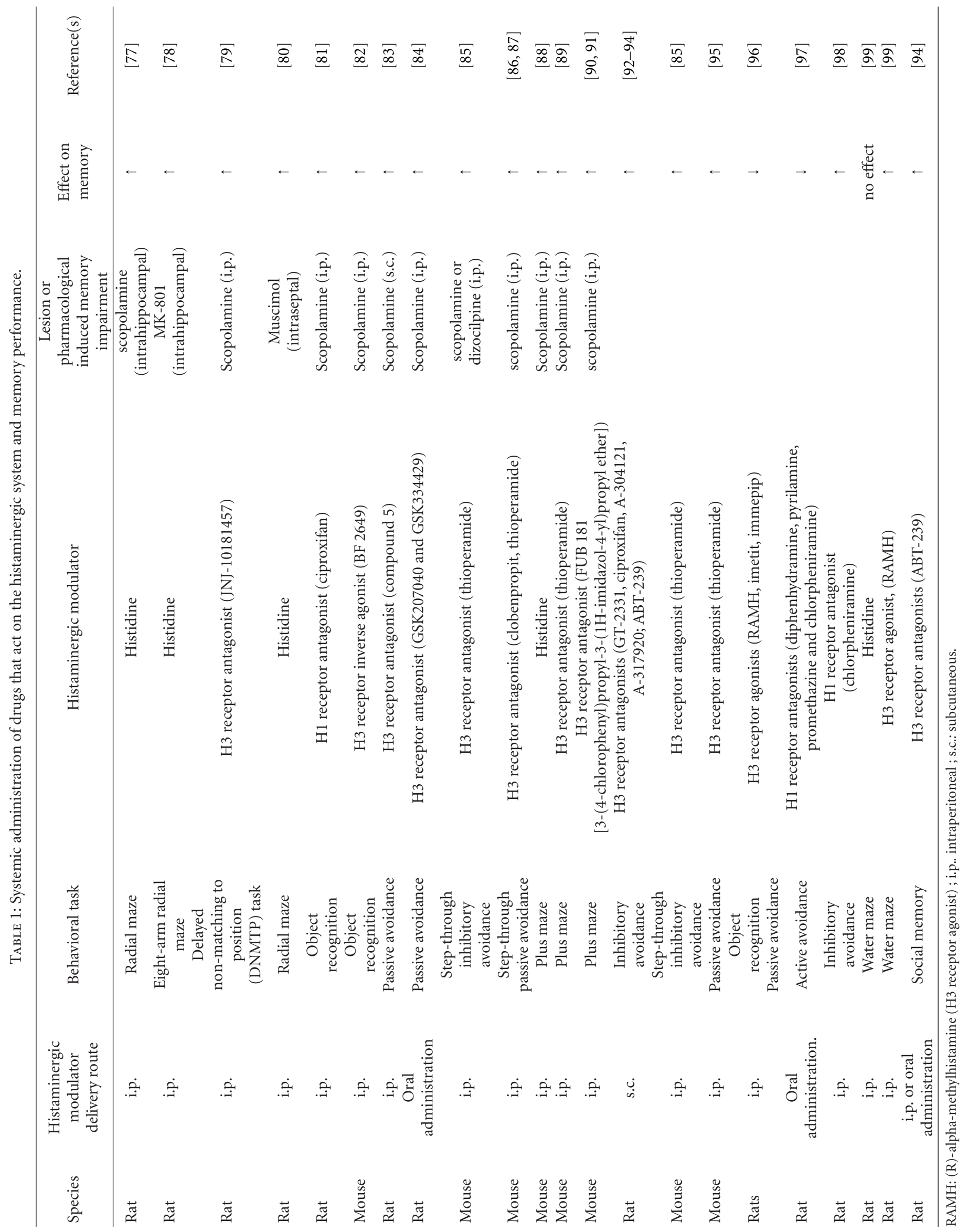


and affinity for studying species receptor [105]. While some studies used classical ligands now classified as inverse agonists (like thioperamide and clobenpropit, which have nonspecific actions, notably on the $5-\mathrm{HT}_{3}$ serotonergic receptor and $\alpha_{2 C}$ adrenergic receptor [105]), studies employing ligands with a different chemical structure and with more selectivity and affinity to the $\mathrm{H} 3$ receptor showed similar memory enhancing effects. By contrast, the administration of an $\mathrm{H} 3$ receptor agonist impairs performance [96], and both non-specific ligands like RAMH (also active on noradrenergic receptors) and imetit (also active on serotonergic receptors) and the more selective ligand immepip produced similar memory impairment effects. Together, these data highlight the possible role of $\mathrm{H3}$-mediated modulation on aversive learning.

On the other hand, the administration of an $\mathrm{H} 1$ receptor antagonist has produced different results for aversive memory tasks $[97,98]$. It must be noted, though, that there is an age difference in the experimental subjects. The expression pattern of the histamine receptor subtypes alters with age in rodents. Since the H1 receptor has the most widespread changes in density [106], this might account for the opposite effect. Finally, the alkylamine chlorpheniramine used in the study also has nonspecific actions, notably the inhibition of noradrenaline and serotonin reuptake, which could also account for the reported effects [107, 108]. Although there are some differences between passive and active avoidance tasks regarding learning (active avoidance involves multitrial learning task, while passive avoidance is singletrial, the latter being more suitable to pharmacologically dissect the role of certain receptors or signaling pathways), the only study that evaluated first generation and the more selective second generation $\mathrm{H} 1$ blockers using active avoidance showed that those nonspecific effects might indeed play a role in the evaluation of the action of $\mathrm{H} 1$ receptors on aversive memory: although all the compounds impaired learning, the extent of the impairment seems to be greater for the nonspecific compounds [98].

The results of systemic studies are contradictory regarding the effect the histaminergic system has on spatial memory tasks such as the water maze (Table 1). The administration of a histamine precursor did not produce any effects, while the administration of an $\mathrm{H} 3$ receptor agonist improved performance [99]. This may be explained by the fact that the $\mathrm{H} 3$ receptor is also found on neurons that release other neurotransmitters, thus improvement could be mediated by the regulation of other systems involved in spatial learning, such as the dopaminergic system $[109,110]$, and not only by increasing the synaptic availability of histamine. Another explanation would be that the $\mathrm{H} 3$ agonist RAMH ligand is not specific to histamine and may also have affinity for other aminergic receptors [105].

6.2. Transgenic Models. Recent studies have used transgenic models to try to identify the role of histamine and each receptor subtype on memory processes. These studies are summarized in Table 3.
There is evidence that the lack of the histamine decarboxylase enzyme produces changes in the performance of some memory tasks although the course might also differ with respect to memory type. In the water maze task, spatial memory has been shown to be both hindered and improved in histamine decarboxylase knockout mice ( $\mathrm{Hdc}-/-$ mice) $[111,112]$ though these differences may be influenced by the gender base used in the models. Thus, although the evidence provided by the transgenic models shows that histamine participates in the modulation of at least some memory systems, the exact course of its actions remains unclear.

Knockout models for $\mathrm{H} 1$ and $\mathrm{H} 2$ receptors, on the other hand, have shed more light on the physiological role of histamine in learning. They act negatively on the learning of aversive tasks but facilitate spatial and discriminative ones. Interestingly, the only study that addresses the role of the three histamine receptors in a Barnes-maze task showed that the lack of an $\mathrm{H} 3$ receptor improves memory. The absence of presynaptic autoinhibitory receptors might potentiate the action of histamine in postsynaptic $\mathrm{H} 1$ and $\mathrm{H} 2$ receptors, which also modulated the memory associated with this particular task (see Table 3 for references).

An important factor in the interpretation of studies with knockout models is that the inactivation of the genes of interest is not restricted to an area or specific part of the circuits involved, and thus, these effects are likely to reflect the overall action of histamine or its receptors. Maybe studies using temporally and spatially restricted knockout models could clarify the role of histamine in each brain site leading to a better understanding regarding how it modulates circuits responsible for processing different memory types.

6.3. Intracerebroventricular (ICV) Administration of Histamine and Memory Performance. The administration of histamine or its receptor agonists/antagonists in the ventricular system is a more convenient way to study the role of histamine in the CNS than peripheral administration, since some ligands might be more prone to cross the blood-brain barrier, and there is less potential for peripheral side effects. In Table 3, we have summarized the studies that employ this delivery route in attempting to address the role of the histaminergic system.

Histamine had facilitatory actions in social learning, since its ICV infusion improved, while the inhibition of its synthesis hindered the performance. Also, pharmacological stimulation with the potent and selective $\mathrm{H} 3$ agonist immepip led to impaired performance in learning the task, while the use of the inverse agonist thioperamide facilitated it. The role of the other receptor types is not addressed, and thus, the $\mathrm{H} 3$ receptor response and histamine effect might be due to the regulation of other neurotransmitter systems.

Conversely, the findings of studies that used tasks based on learning an aversive memory are controversial. Studies that employed a passive avoidance task showed either improvement or impairment of the task following ICV administration of histamine [120-124], but the doses administered varied: $1-10 \mathrm{ng} / \mathrm{rat}$ of histamine improved performance, while $20 \mu \mathrm{g} / \mathrm{rat}$ impaired it. $\mathrm{EC}_{50}$ of the $\mathrm{H} 3$ 
TABLE 2: Knockout mice models and memory performance.

\begin{tabular}{|c|c|c|c|}
\hline Behavioral task & Knockout type & Effect on memory & Reference(s) \\
\hline Water maze* & $\mathrm{Hdc}-/-$ & $\downarrow$ & {$[111]$} \\
\hline Water maze & $\mathrm{Hdc}-1-$ & $\uparrow$ & {$[112]$} \\
\hline Object recognition* & $\mathrm{Hdc}-1-$ & Unaffected & {$[111]$} \\
\hline $\begin{array}{l}\text { Nonreinforced episodic object } \\
\text { memory }\end{array}$ & $\mathrm{Hdc}-/-$ & $\downarrow$ & {$[112]$} \\
\hline Contextual fear conditioning & $\mathrm{Hdc}-/-$ & $\uparrow$ & {$[113]$} \\
\hline One-trial passive avoidance & $\mathrm{Hdc}-/-$ & $\uparrow$ & {$[111]$} \\
\hline Open field (habituation) & $\mathrm{Hdc}-/-$ & Unaffected & {$[114]$} \\
\hline Inhibitory avoidance & KO H1-/- & Unaffected & {$[115]$} \\
\hline Conditioned place preference & KO H1-/- & $\downarrow$ & {$[116]$} \\
\hline Radial-maze task & KO H1-/- & $\downarrow$ & {$[117]$} \\
\hline $\begin{array}{l}\text { Auditory and contextual fear } \\
\text { conditioning }\end{array}$ & KO H1-/- & $\uparrow$ & {$[68]$} \\
\hline $\begin{array}{l}\text { Auditory and contextual fear } \\
\text { conditioning }\end{array}$ & $\mathrm{KO} \mathrm{H} 2-1-$ & $\uparrow$ & {$[68]$} \\
\hline Object recognition & $\mathrm{KO} \mathrm{H1-/-}$ & $\downarrow$ & {$[68]$} \\
\hline Object recognition & $\mathrm{KO} \mathrm{H} 2-1-$ & $\downarrow$ & {$[68]$} \\
\hline Barnes maze & KO H1-/- & $\downarrow$ & {$[68]$} \\
\hline Barnes maze & $\mathrm{KO} \mathrm{H} 2-1-$ & $\downarrow$ & {$[68]$} \\
\hline Barnes maze & $\mathrm{KO} \mathrm{H} 3-/-$ & $\uparrow$ & {$[118]$} \\
\hline Motoric long-term memory & KO H1-/- & $\downarrow$ & {$[119]$} \\
\hline $\begin{array}{l}\text { Episodic and procedural } \\
\text { memory }\end{array}$ & KO H1-/- & $\downarrow$ & [119] \\
\hline
\end{tabular}

* This work was done using female mice.

Hdc: histidine decarboxylase.

$\mathrm{H} 1, \mathrm{H} 2, \mathrm{H} 3$ : histaminergic receptor type.

receptors are at least one order of magnitude lower than $\mathrm{H} 1$ and $\mathrm{H} 2$ receptors [13], and thus, the low concentration might be causing a mainly $\mathrm{H} 3$-based response, thus acting negatively on the histaminergic system, which would explain the reported improvement in aversive memory. Since $\mathrm{H} 1$ and $\mathrm{H} 2$ receptor blockage also improved the memory for the same task, this would corroborate the inhibitory actions of histamine in aversive learning [122-124].

The findings of two studies employing the active avoidance paradigm were also contradictory $[127,135]$, but the study that showed memory improvement was found with the use of aged rats, which might account for the reported contradictory effects. Finally, there is controversy regarding the role of the $\mathrm{H} 1$ receptor in the active avoidance task, since it was shown that this could either inhibit or facilitate performance in active avoidance tasks $[127,132]$.

The ICV administration of compounds that act on the histaminergic system is less studied in spatial memory and object recognition or discriminative memory types. Histamine reverses the impairment induced by NMDA antagonists in a radial maze task [130]. The activation of both glycine and polyamine sites can act synergistically in memory function [136], and thus, histamine might compensate the deficit through direct action on the NMDA receptor. However, in a physiological context, the blockage of histamine synthesis [131] or lack of the gene that encodes the $\mathrm{H} 1$ receptor impaired performance in the radial maze [117], while $\mathrm{H} 1$ receptor inactivation improved the memory in the water-maze task [134]. Methodological particularities of these tasks that rely on spatial memory might explain this differential effect. H1 receptor activation facilitated learning the object recognition task, and this is in agreement with studies that used knockout models (Table 3 ). The brain areas involved are slightly different for spatial and discriminative tasks, with spatial memory depending mainly on the hippocampus, while discriminative memory relies on other cortical areas, such as the perirhinal cortex [137-139]. Thus, the different roles the H1 receptor seems to have in spatial and recognition memory might rely on those distinct anatomic requirements, since the density of $\mathrm{H} 1$ receptors is different in the cortex and the hippocampus.

6.4. Administration of Histamine into the Hippocampus and Memory Performance. The hippocampal formation is composed of three subregions: the Ammon's horn, the dentate gyrus, and the subiculum. The Ammon's horn is further divided into the subfields CA1-CA4. These subregions are connected to form a closed-loop circuit with the adjacent entorhinal cortex (EC). Neurons from the layer II of the EC project to the dentate gyrus and the CA3 subfield, while neurons from layer III project directly to CA1. The 
TABLE 3: Intracerebroventricular administration of drugs that act on the histaminergic system and memory performance.

\begin{tabular}{|c|c|c|c|c|c|}
\hline Species & Behavioral task & Histaminergic modulator & $\begin{array}{c}\text { Lesion or pharmacological } \\
\text { induced memory } \\
\text { impairment }\end{array}$ & $\begin{array}{l}\text { Effect on } \\
\text { memory }\end{array}$ & Reference(s) \\
\hline Rat & Passive avoidance & Histamine & & $\uparrow$ & {$[120,121]$} \\
\hline Rat & Passive avoidance & Histamine & & $\downarrow$ & {$[122-124]$} \\
\hline Mouse & Passive avoidance & Histamine & Lithium (i.p.) & $\uparrow$ & [125] \\
\hline Rat & Active avoidance & Histamine & & $\uparrow$ & {$[126]$} \\
\hline Rat & Active avoidance & Histamine & & $\downarrow$ & {$[127]$} \\
\hline Rat & Active avoidance & Histamine & $\begin{array}{l}\text { Bilateral hippocampectomy } \\
\text { (dorsal hippocampus) }\end{array}$ & $\uparrow$ & {$[128]$} \\
\hline Rat & Active avoidance & Histamine & alpha-FMH (i.p.) & $\uparrow$ & {$[126]$} \\
\hline Rat & Habituation in open field & Histamine & & $\uparrow$ & {$[121]$} \\
\hline Rat & Social memory & Histamine & & $\uparrow$ & {$[129]$} \\
\hline Rat & Social memory & Histidine & & $\uparrow$ & {$[129]$} \\
\hline Rat & Social memory & alpha-FMH & & $\downarrow$ & [129] \\
\hline Rat & Radial maze & Histamine & $\begin{array}{c}\text { N-methyl- d-aspartate } \\
\text { (NMDA) receptor glycine } \\
\text { site antagonist } \\
\text { (7-chlorokynurenic acid) } \\
\text { i.c.v }\end{array}$ & $\uparrow$ & {$[130]$} \\
\hline Rat & Radial maze & alpha-FMH & & $\downarrow$ & {$[131]$} \\
\hline Rat & Passive avoidance & $\begin{array}{l}\text { H1 receptor antagonist } \\
\text { (chlorpheniramine) }\end{array}$ & & $\uparrow$ & {$[122]$} \\
\hline Rat & Passive avoidance & $\begin{array}{l}\text { H1 receptor antagonist } \\
\text { (pyrilamine ) }\end{array}$ & & $\uparrow$ & {$[124]$} \\
\hline Rat & Passive avoidance & $\begin{array}{l}\mathrm{H} 2 \text { receptor antagonist } \\
\text { (cimetidine) }\end{array}$ & & $\uparrow$ & {$[123,124]$} \\
\hline Mouse & Passive avoidance & $\begin{array}{l}\text { H2 receptor agonist } \\
\text { (4-methylhistamine) }\end{array}$ & & $\downarrow$ & {$[90]$} \\
\hline Rat & Active avoidance & $\begin{array}{l}\text { H1 receptor agonist } \\
\text { (2-methylhistamine and } \\
\text { 2-thiazolylethylamine) }\end{array}$ & & $\downarrow$ & {$[127]$} \\
\hline Rat & $\begin{array}{l}\text { Step-through active } \\
\text { avoidance }\end{array}$ & $\begin{array}{l}\text { H1 receptor agonist } \\
\text { (2-methylhistamine) }\end{array}$ & & $\uparrow$ & {$[132]$} \\
\hline Rat & $\begin{array}{l}\text { Step-through active } \\
\text { avoidance }\end{array}$ & $\begin{array}{l}\text { H1 receptor antagonist } \\
\text { (pyrilamine or } \\
\text { diphenhydramine) }\end{array}$ & & $\downarrow$ & {$[132]$} \\
\hline Rat & Social memory & $\begin{array}{l}\text { H3 receptor agonist } \\
\text { (immepip) }\end{array}$ & & $\downarrow$ & [129] \\
\hline Rat & Social memory & $\begin{array}{l}\mathrm{H} 3 \text { receptor antagonist } \\
\text { (thioperamide) }\end{array}$ & & $\uparrow$ & [129] \\
\hline Rat & Object recognition & $\begin{array}{l}\text { H1 receptor agonist } \\
\text { [2-(3-(trifluoromethyl)- } \\
\text { phenyl)histamine] }\end{array}$ & & $\uparrow$ & {$[133]$} \\
\hline Rat & Water maze & $\begin{array}{l}\text { H1 receptor antagonist } \\
\text { (chlorpheniramine) }\end{array}$ & & $\uparrow$ & {$[134]$} \\
\hline
\end{tabular}

alpha-FMH: alpha-fluoromethylhistidine (inhibitor of histamine decarboxylase)

i.p. intraperitoneal

i.c.v intracerebroventricular.

projections from the EC are known as the perforant pathway. Neurons from the DG project to the CA3 subfield, through the mossy fiber pathway. CA3 neurons make synapse with neurons from the CA1 region through the Schaffer collateral pathway. Finally, to close the loop, the CA1 region neurons project to the layer $V$ of the entorhinal cortex $[148,149]$.
The superficial entorhinal layers receive input from other cortical areas and the olfactory bulb. The CA1 area is the main output of the hippocampus, which is directed mainly to the EC, which act as a hub to other cortical areas. The hippocampus can also project to subcortical areas, mainly through subiculum. Among the subcortical 
TABLE 4: Intrahippocampal administration of drugs that act on the histaminergic system and memory performance.

\begin{tabular}{|c|c|c|c|c|c|}
\hline Species & Hippocampal site & Behavioral task & Histaminergic modulator & Effect on memory & Reference $(\mathrm{s})$ \\
\hline Rat $^{1}$ & Dorsal & Inhibitory avoidance & Histamine & $\uparrow$ & {$[140]$} \\
\hline Rat $^{2}$ & Ventral & One-way active avoidance & Histamine & $\downarrow$ & {$[141-143]$} \\
\hline Rat & Dorsal & One-way active avoidance & Histamine & Unaffected & [143] \\
\hline $\operatorname{Rat}^{2,3}$ & Dorsal & Eight-arm radial maze & Histamine & $\uparrow$ & {$[78]$} \\
\hline $\mathrm{Rat}^{4}$ & Intrahippocampal & Radial maze & Histamine & $\uparrow$ & {$[80]$} \\
\hline Rat & Dorsal & Inhibitory avoidance & $\begin{array}{c}\mathrm{H} 2 \text { receptor agonist } \\
\text { (dimaprit) }\end{array}$ & $\uparrow$ & {$[140]$} \\
\hline Rat $^{5}$ & Ventral & Active avoidance & $\begin{array}{l}\mathrm{H} 3 \text { receptor antagonist } \\
\text { (clobenpropit) }\end{array}$ & $\uparrow$ & {$[144]$} \\
\hline Rat & Dorsal & $\begin{array}{l}\text { Contextual fear } \\
\text { conditioning }\end{array}$ & $\begin{array}{c}\text { H2 receptor agonist } \\
\text { (amthamine) }\end{array}$ & $\uparrow$ & {$[145]$} \\
\hline Rat & Dorsal & $\begin{array}{l}\text { Contextual fear } \\
\text { conditioning }\end{array}$ & $\begin{array}{l}\text { H3 receptor agonist } \\
(\mathrm{RAMH})\end{array}$ & $\uparrow$ & {$[145]$} \\
\hline $\mathrm{Rat}^{3}$ & Dorsal & Eight-arm radial maze & $\begin{array}{l}\text { H3 receptor antagonist } \\
\text { (clobenpropit) }\end{array}$ & $\uparrow$ & {$[146]$} \\
\hline Rat & Dorsal & Three-panel runway & $\begin{array}{l}\text { H1 receptor antagonist } \\
\text { (pyrilamine) }\end{array}$ & $\downarrow$ & {$[147]$} \\
\hline
\end{tabular}

RAMH: (R)-(-)-alpha-methylhistamine

${ }^{1}$ Effect reverted with concomitant administration of the $\mathrm{H} 2$ receptor antagonist ranitidine

${ }^{2}$ Effect reverted with concomitant administration of the $\mathrm{H} 1$ receptor antagonist pyrilamine

${ }^{3}$ Impairment induced using intrahippocampal injection of MK-801

${ }^{4}$ Impairment induced using intraseptal injection of muscimol

${ }^{5}$ Impairment induced using intrahippocampal injection of scopolamine.

TABLE 5: Administration of drugs that act on the histaminergic system into the amygdala and memory performance.

\begin{tabular}{|c|c|c|c|c|c|}
\hline Species & Amygdala site & Behavioral task & Histaminergic modulator & $\begin{array}{l}\text { Effect on } \\
\text { memory }\end{array}$ & Reference(s) \\
\hline Rat & Basolateral & Active avoidance & Histamine & $\downarrow$ & {$[144]$} \\
\hline Rat & Basolateral & $\begin{array}{l}\text { Contextual fear } \\
\text { conditioning }\end{array}$ & $\begin{array}{l}\mathrm{H} 3 \text { receptor antagonists } \\
\text { (ciproxifan, clobenpropit } \\
\text { and thioperamide) }\end{array}$ & $\downarrow$ & {$[154]$} \\
\hline Rat & Basolateral & $\begin{array}{l}\text { Contextual fear } \\
\text { conditioning }\end{array}$ & $\begin{array}{l}\text { H3 receptor agonists } \\
\text { (RAMH or Immepip) }\end{array}$ & $\uparrow$ & {$[144,155]$} \\
\hline Rat & Basolateral & $\begin{array}{l}\text { Contextual fear } \\
\text { conditioning }\end{array}$ & $\begin{array}{l}\text { H3 receptor agonist } \\
\text { (proxifan) }\end{array}$ & $\uparrow$ & {$[156]$} \\
\hline
\end{tabular}

RAMH: (R)-(-)-alpha-methylhistamine.

input to the hippocampus are projections from the septum, amygdala, thalamic nuclei, diagonal band of Broca, the basal nucleus of Meynert, the tuberomammillary nucleus, the ventral tegmental area, the raphe nuclei, and the locus coeruleus. Finally, the connectivity of the hippocampus to other structures differs with respect to its dorsoventral axis [148-150].

The hippocampus is central in spatial memory tasks [56], and the NMDA receptor plays an important role in this type of learning [151]. The impairment in radial maze learning induced by the NMDA receptor antagonist MK-801 could be reversed by the direct administration of histamine in the hippocampus [78]. Since the blockage of the H3 receptor in this structure had a similar effect and the reversal was hindered by the administration of an $\mathrm{H} 1$ receptor antagonist [78], the observed improvement might be due to the increased synaptic availability of histamine and its binding to postsynaptic $\mathrm{H} 1$ receptors [78]. The modulation of the excitability of hippocampal cells through the $\mathrm{H} 1$ and $\mathrm{H} 2$ receptors [13] and the direct activation of the NMDA receptor through the polyamine site $[65,66]$ are possible mechanisms to mediate the observed effects.

The inhibition of the septum or the administration of scopolamine cause memory deficits that are reversed by histamine or the $\mathrm{H} 3$ receptor antagonist clobenpropit (Table 4). Together with the mechanisms described for the modulation of the septohippocampal pathway [102], histamine seems to locally regulate $\mathrm{ACh}$ release in the hippocampus.

The hippocampus is also required for learning aversive tasks like inhibitory avoidance and contextual fear conditioning $[10,152]$. There is a possible anatomical dissociation within this region regarding the effects of histamine on aversive tasks, since in the dorsal hippocampus histamine seems to facilitate both fear conditioning and passive avoidance through the $\mathrm{H} 2$ receptor, while in the ventral area, it has inhibitory effects on active avoidance through the $\mathrm{H} 1$ 
receptor (Table 4). The extent to which the methodological peculiarities of each aversive paradigm play a role in this dissociation remains unclear. In addition, there is evidence that the hippocampus has a functional segmentation in its dorsoventral axis, with spatially distinct molecular domains and subdomains [150]. This might lead to differences in receptor density or downstream signaling pathways that together could account for the observed results.

Thus, the mechanisms that mediate the effects seen in this area may result from the interplay of histamine with cholinergic and other aminergic systems, direct activation of the glutamatergic system through the NMDA receptor, or by cellular downstream cascades activated from a particular receptor, with a possible overall combination of one or more mechanisms $[13,153]$ that altogether could account for discrepancies and differential involvement of histamine in a particular memory task.

6.5. Administration of Histamine into the Amygdala and Memory Performance. The amygdala is a complex mass of gray matter that comprises multiple and distinct subnuclei and is richly connected to nearby cortical areas that constitute the amygdala circuitry. The amygdala contains three functional subdivisions, each one having a unique set of connections with other regions of the brain. The medial group of subnuclei has extensive connections with the olfactory bulb and the olfactory cortex. The basolateral group, which is especially large in humans, has major connections with the cerebral cortex, especially the orbital and medial prefrontal cortex. The central and anterior group of nuclei is characterized by connections with the brainstem and hypothalamus and with visceral sensory structures, such as the nucleus of the solitary tract. For more details about the general organization of the amygdala anatomy circuitry, see [157].

Previous studies have clearly identified the amygdala as a key brain structure for acquisition and storage of several memory types, first among them, fear memory. Classical fear conditioning is a powerful behavioral paradigm that has been widely studied in amygdala nuclei and mainly in the basolateral amygdala nucleus (BLA), which have been shown to participate in the learning and memory consolidation mechanism [158]. These findings are consistently supported by a large number of studies using different experimental paradigms and measures of aversive memory [158, 159]. In addition, the amygdala also modulates fear-related learning in the other brain structures, such as the cortex and the hippocampus [160].

The studies that investigate the modulatory effects of histamine in the BLA are summarized in Table 5. Electrophysiological studies in rat brain slices revealed that histamine can have bidirectional effects on excitatory synaptic transmission in BLA depending on the blockage of $\mathrm{H} 3$ receptors: the excitatory postsynaptic potential was depressed in the presence of histamine alone but increased when the $\mathrm{H} 3$ receptor antagonist thioperamide was added to the preparation [161]. Behavioral models, however, are better suited to study such effects, since the slice preparation lacks afferent and efferent projections. Few behavioral studies have evaluated the role of histamine in amygdala.

Evidence using the fear conditioning task with pharmacological agonists/antagonists showed that blockage of the $\mathrm{H} 3$ receptors has inhibitory actions, while their activation improves the expression of fear memory. It has been shown that the modulation of ACh release in amygdala through the $\mathrm{H} 3$ receptor participates in this modulation, since rats that received the infusion of $\mathrm{H} 3$ receptor antagonists in the BLA at similar concentrations to those that affected fear memory had a significant reduction in the spontaneous release of ACh [154]. New approaches using transgenic models agree with the inhibitory role for histamine in fear memory, since the lack of $\mathrm{H} 1$ and $\mathrm{H} 2$ receptors improves memory for this task, and mice with reduced levels of histamine due to lack of histamine decarboxylase also have improved performance although the inactivation was not restricted to the BLA (Table 3). Along with pharmacological data, this suggests that these inhibitory effects might also be mediated by the $\mathrm{H} 1$ and $\mathrm{H} 2$ receptors.

\section{Conclusion}

Together, these studies suggest that the manipulation of the central histaminergic system affects behavioral responses during several learning and memory processes. However, the results are often contradictory and do not establish whether the overall action of histamine on the memory system is either facilitatory or inhibitory. Methodological issues, such as time and the methods used in the administration of the compounds under scrutiny as well as the parameters related to the behavioral task under evaluation need to be taken into consideration. Furthermore, in view of the opposite effects that the activation of the different histamine-receptor subtypes has on memory due to the variability of cellular action, the final course of action of histamine in a network is not predictable.

\section{Conflict of Interests}

The authors declare that they have no conflict of interest.

\section{Acknowledgment}

The authors wish to thank Professor Dr. Martin Cammarota for his helpful insights in the elaboration of this paper.

\section{References}

[1] J. L. McGaugh, "Time-dependent processes in memory storage," Science, vol. 153, no. 742, pp. 1351-1358, 1966.

[2] J. L. Mcgaugh, L. Cahill, and B. Roozendaal, "Involvement of the amygdala in memory storage: interaction with other brain systems," Proceedings of the National Academy of Sciences of the United States of America, vol. 93, no. 24, pp. 13508-13514, 1996.

[3] B. Milner, L. R. Squire, and E. R. Kandel, "Cognitive neuroscience and the study of memory," Neuron, vol. 20, no. 3, pp. 445-468, 1998. 
[4] E. R. Kandel and L. R. Squire, "Neuroscience: breaking down scientific barriers to the study of brain and mind," Science, vol. 290, no. 5494, pp. 1113-1120, 2000.

[5] L. R. Squire and E. Kandel, Memory: From Mind to Molecules, Roberts \& Company Publishers, Greenwood Village, Colo, USA, 2008.

[6] I. Izquierdo, J. H. Medina, M. R. M. Vianna, L. A. Izquierdo, and D. M. Barros, "Separate mechanisms for short- and longterm memory," Behavioural Brain Research, vol. 103, no. 1, pp. 1-11, 1999.

[7] L. Cahill and J. L. McGaugh, "Mechanisms of emotional arousal and lasting declarative memory," Trends in Neurosciences, vol. 21, no. 7, pp. 294-299, 1998.

[8] I. Izquierdo, Memória, Artmed, Porto Alegre, Brazil, 2002.

[9] P. Ardenghi, D. Barros, L. A. Izquierdo et al., "Late and prolonged post-training memory modulation in entorhinal and parietal cortex by drugs acting on the cAMP/protein kinase A signalling pathway," Behavioural Pharmacology, vol. 8, no. 8, pp. 745-751, 1997.

[10] I. Izquierdo and J. H. Medina, "Memory formation: the sequence of biochemical events in the hippocampus and its connection to activity in other brain structures," Neurobiology of Learning and Memory, vol. 68, no. 3, pp. 285-316, 1997.

[11] D. M. Barros, T. Mello E Souza, T. De David et al., "Simultaneous modulation of retrieval by dopaminergic $D_{1}, \beta$ noradrenergic, serotonergic-1A and cholinergic muscarinic receptors in cortical structures of the rat," Behavioural Brain Research, vol. 124, no. 1, pp. 1-7, 2001.

[12] I. Izquierdo and J. L. McGaugh, "Behavioural pharmacology and its contribution to the molecular basis of memory consolidation," Behavioural Pharmacology, vol. 11, no. 7-8, pp. 517-534, 2000.

[13] R. E. Brown, D. R. Stevens, and H. L. Haas, "The physiology of brain histamine," Progress in Neurobiology, vol. 63, no. 6, pp. 637-672, 2001.

[14] H. Haas and P. Panula, "The role of histamine and the tuberomamillary nucleus in the nervous system," Nature Reviews Neuroscience, vol. 4, no. 2, pp. 121-130, 2003.

[15] H. L. Haas and A. Konnerth, "Histamine and noradrenaline decrease calcium-activated potassium conductance in hippocampal pyramidal cells," Nature, vol. 302, no. 5907, pp. 432-434, 1983.

[16] O. Selbach, R. E. Brown, and H. L. Haas, "Long-term increase of hippocampal excitability by histamine and cyclic AMP," Neuropharmacology, vol. 36, no. 11-12, pp. 1539-1548, 1997.

[17] A. Knoche, H. Yokoyama, A. Ponomarenko, C. Frisch, J. Huston, and H. L. Haas, "High-frequency oscillation in the hippocampus of the behaving rat and its modulation by the histaminergic system," Hippocampus, vol. 13, no. 2, pp. 273280, 2003.

[18] A. A. Ponomarenko, A. Knoche, T. M. Korotkova, and H. L. Haas, "Aminergic control of high-frequency (approximately $200 \mathrm{~Hz}$ ) network oscillations in the hippocampus of the behaving rat," Neuroscience Letters, vol. 348, no. 2, pp. 101104, 2003.

[19] J. M. Bekkers, "Enhancement by histamine of NMDAmediated synaptic transmission in the hippocampus," Science, vol. 261, no. 5117, pp. 104-106, 1993.

[20] N. Inagaki, A. Yamatodani, M. Ando-Yamamoto, M. Tohyama, T. Watanabe, and H. Wada, "Organization of histaminergic fibers in the rat brain," The Journal of Comparative Neurology, vol. 273, no. 3, pp. 283-300, 1988.
[21] J. C. Schwartz, J. M. Arrang, M. Garbarg, H. Pollard, and M. Ruat, "Histaminergic transmission in the mammalian brain," Physiological Reviews, vol. 71, no. 1, pp. 1-51, 1991.

[22] P. Panula, U. Pirvola, S. Auvinen, and M. S. Airaksinen, "Histamine-immunoreactive nerve fibers in the rat brain," Neuroscience, vol. 28, no. 3, pp. 585-610, 1989.

[23] H. Ericson, A. Blomqvist, and C. Kohler, "Origin of neuronal inputs to the region of the tuberomammillary nucleus of the rat brain," The Journal of Comparative Neurology, vol. 311, no. 1, pp. 45-64, 1991.

[24] H. Ericson, A. Blomqvist, and C. Kohler, "Brainstem afferents to the tuberomammillary nucleus in the rat brain with special reference to monoaminergic innervation," The Journal of Comparative Neurology, vol. 281, no. 2, pp. 169-192, 1989.

[25] H. Prast, H. P. Fischer, M. Prast, and A. Philippu, "In vivo modulation of histamine release by autoreceptors and muscarinic acetylcholine receptors in the rat anterior hypothalamus," Naunyn-Schmiedeberg's Archives of Pharmacology, vol. 350, no. 6, pp. 599-604, 1994.

[26] J. M. Arrang, C. Gulat-Marnay, N. Defontaine, and J. C. Schwartz, "Regulation of histamine release in rat hypothalamus and hippocampus by presynaptic galanin receptors," Peptides, vol. 12, no. 5, pp. 1113-1117, 1991.

[27] C. Gulat-Marnay, A. Lafitte, J. M. Arrang, and J. C. Schwartz, "Regulation of histamine release and synthesis in the brain by muscarinic receptors," Journal of Neurochemistry, vol. 52, no. 1, pp. 248-254, 1989.

[28] H. Prast, M. Heistracher, and A. Philippu, "In vivo modulation of the histamine release in the hypothalamus by adrenoreceptor agonists and antagonists," NaunynSchmiedeberg's Archives of Pharmacology, vol. 344, no. 2, pp. 183-186, 1991.

[29] C. Gulat-Marnay, A. Lafitte, J. M. Arrang, and J. C. Schwartz, "Modulation of histamine release and synthesis in the brain mediated by alpha 2-adrenoceptors," Journal of Neurochemistry, vol. 53, no. 2, pp. 513-518, 1989.

[30] R. Oishi, Y. Itoh, and K. Saeki, "Inhibition of histamine turnover by 8-OH-DPAT, buspirone and 5hydroxytryptophan in the mouse and rat brain," NaunynSchmiedeberg's Archives of Pharmacology, vol. 345, no. 5, pp. 495-499, 1992.

[31] C. Gulat-Marnay, A. Lafitte, J. M. Arrang, and J. C. Schwartz, "Modulation of histamine release in the rat brain by $\kappa$-opioid receptors," Journal of Neurochemistry, vol. 55, no. 1, pp. 4753, 1990.

[32] Y. Itoh, R. Oishi, M. Nishibori, and K. Saeki, "Involvement of $\mathrm{Mu}$ receptors in the opioid-induced increase in the turnover of mouse brain histamine," The Journal of Pharmacology and Experimental Therapeutics, vol. 244, no. 3, pp. 1021-1026, 1988.

[33] T. Mochizuki, A. Yamatodani, K. Okakura, A. Horii, N. Inagaki, and H. Wada, "Circadian rhythm of histamine release from the hypothalamus of freely moving rats," Physiology and Behavior, vol. 51, no. 2, pp. 391-394, 1992.

[34] J. E. Sherin, P. J. Shiromani, R. W. McCarley, and C. B. Saper, "Activation of ventrolateral preoptic neurons during sleep," Science, vol. 271, no. 5246, pp. 216-219, 1996.

[35] T. L. Steininger, H. Gong, D. Mcginty, and R. Szymusiak, "Subregional organization of preoptic area/anterior hypothalamic projections to arousal-related monoaminergic cell groups," The Journal of Comparative Neurology, vol. 429, no. 4, pp. 638-653, 2001. 
[36] A. Philippu and H. Prast, "Patterns of histamine release in the brain," Agents and Actions, vol. 33, no. 1-2, pp. 124-125, 1991.

[37] D. A. McCormick and A. Williamson, "Modulation of neuronal firing mode in cat and guinea pig LGNd by histamine: possible cellular mechanisms of histaminergic control of arousal," Journal of Neuroscience, vol. 11, no. 10, pp. 3188-3199, 1991.

[38] M. Munakata and N. Akaike, "Regulation of $\mathrm{K}^{+}$conductance by histamine $\mathrm{H}_{1}$ and $\mathrm{H}_{2}$ receptors in neurones dissociated from rat neostriatum," The Journal of Physiology, vol. 480, no. 2, pp. 233-245, 1994.

[39] P. B. Reiner and A. Kamondi, "Mechanisms of antihistamineinduced sedation in the human brain: $\mathrm{H}_{1}$ receptor activation reduces a background leakage potassium current," Neuroscience, vol. 59, no. 3, pp. 579-588, 1994.

[40] R. E. Brown and H. L. Haas, "On the mechanism of histaminergic inhibition of glutamate release in the rat dentate gyrus," The Journal of Physiology, vol. 515, no. 3, pp. 777-786, 1999.

[41] E. Schlicker, A. Behling, G. Lummen, and M. Gothert, "Histamine $\mathrm{H} 3 \mathrm{~A}$ receptor-mediated inhibition of noradrenaline release in the mouse brain cortex," Naunyn-Schmiedeberg's Archives of Pharmacology, vol. 345, no. 4, pp. 489-493, 1992.

[42] M. Yamashita, H. Fukui, K. Sugama et al., "Expression cloning of a cDNA encoding the bovine histamine $\mathrm{H}_{1}$ receptor," Proceedings of the National Academy of Sciences of the United States of America, vol. 88, no. 24, pp. 11515-11519, 1991.

[43] M. Lintunen, T. Sallmen, K. Karlstedt, H. Fukui, K. S. Eriksson, and P. Panula, "Postnatal expression of $\mathrm{H}_{1}$-receptor mRNA in the rat brain: correlation to L-histidine decarboxylase expression and local upregulation in limbic seizures," The European Journal of Neuroscience, vol. 10, no. 7, pp. 22872301, 1998.

[44] J. W. Black, W. A. Duncan, C. J. Durant, C. R. Ganellin, and E. M. Parsons, "Definition and antagonism of histamine $\mathrm{H}_{2}$ Receptors," Nature, vol. 236, no. 5347, pp. 385-390, 1972.

[45] I. Gantz, M. Schaffer, J. DelValle et al., "Molecular cloning of a gene encoding the histamine $\mathrm{H}_{2}$ receptor," Proceedings of the National Academy of Sciences of the United States of America, vol. 88, no. 13, p. 5937, 1991.

[46] S. A. Josselyn and P. V. Nguyen, "CREB, synapses and memory disorders: past progress and future challenges," Current Drug Targets, vol. 4, no. 5, pp. 481-497, 2005.

[47] F. Coge, S. P. Guenin, V. Audinot et al., "Genomic organization and characterization of splice variants of the human histamine $\mathrm{H}_{3}$ receptor," Biochemical Journal, vol. 355, no. 2, pp. 279-288, 2001.

[48] G. Drutel, N. Peitsaro, K. Karlstedt et al., "Identification of rat $\mathrm{H}_{3}$ receptor isoforms with different brain expression and signaling properties," Molecular Pharmacology, vol. 59, no. 1, pp. 1-8, 2001.

[49] J. M. Arrang, M. Garbarg, and J. C. Schwartz, "Autoinhibition of brain histamine release mediated by a novel class $\left(\mathrm{H}_{3}\right)$ of histamine receptor," Nature, vol. 302, no. 5911, pp. 832-837, 1983.

[50] Y. Itoh, R. Oishi, M. Nishibori, and K. Saeki, "Characterization of histamine release from the rat hypothalamus as measured by in vivo microdialysis," Journal of Neurochemistry, vol. 56, no. 3, pp. 769-774, 1991.

[51] S. Morisset, A. Rouleau, X. Ligneau et al., "High constitulive activity of native $\mathrm{H}_{3}$ receptors regulates histamine neurons in brain," Nature, vol. 408, no. 6814, pp. 860-864, 2000.
[52] E. Schlicker, B. Malinowska, M. Kathmann, and M. Gothert, "Modulation of neurotransmitter release via histamine $\mathrm{H}_{3}$ heteroreceptors," Fundamental and Clinical Pharmacology, vol. 8, no. 2, pp. 128-137, 1994.

[53] S. J. Hill, C. R. Ganellin, H. Timmerman et al., "International union of pharmacology. XIII. Classification of histamine receptors," Pharmacological Reviews, vol. 49, no. 3, pp. 253278, 1997.

[54] J. C. Schwartz and J. M. Arrang, "Histamine," in Neuropsychopharmacology: The Fifth Generation of Progress, L. W. A. Wilkins, Ed., Philadelphia, Pa, USA, 2002.

[55] C. Pillot, A. Heron, V. Cochois et al., "A detailed mapping of the histamine $\mathrm{H}_{3}$ receptor and its gene transcripts in rat brain," Neuroscience, vol. 114, no. 1, pp. 173-193, 2002.

[56] S. H. Wang and R. G. Morris, "Hippocampal-neocortical interactions in memory formation, consolidation, and reconsolidation," Annual Review of Psychology, vol. 61, pp. 49-79, 2010.

[57] T. V. Bliss and T. Lomo, "Long lasting potentiation of synaptic transmission in the dentate area of the anaesthetized rabbit following stimulation of the perforant path," The Journal of Physiology, vol. 232, no. 2, pp. 331-356, 1973.

[58] W. B. Scoville and B. Milner, "Loss of recent memory after bilateral hippocampal lesions," Journal of Neurology, Neurosurgery, and Psychiatry, vol. 20, no. 1, pp. 11-21, 1957.

[59] M. A. Lynch, "Long-term potentiation and memory," Physiological Reviews, vol. 84, no. 1, pp. 87-136, 2004.

[60] R. C. Malenka and M. F. Bear, "LTP and LTD: an embarrassment of riches," Neuron, vol. 44, no. 1, pp. 5-21, 2004.

[61] J. D. Sweatt, "Toward a molecular explanation for long-term potentiation," Learning and Memory, vol. 6, no. 5, pp. 399416, 1999.

[62] W. X. Zhong, Z. F. Dong, M. Tian, J. Cao, L. Xu, and J. H. Luo, "N-methyl-D-aspartate receptor-dependent long-term potentiation in CA1 region affects synaptic expression of glutamate receptor subunits and associated proteins in the whole hippocampus," Neuroscience, vol. 141, no. 3, pp. 13991413, 2006.

[63] H. C. Dringenberg and M. C. Kuo, "Cholinergic, histaminergic, and noradrenergic regulation of LTP stability and induction threshold: cognitive implications," EXS, vol. 98, pp. 165-183, 2006.

[64] K. Williams, "Subunit-specific potentiation of recombinant N-methyl-D-aspartate receptors by histamine," Molecular Pharmacology, vol. 46, no. 3, pp. 531-541, 1994.

[65] V. S. Vorobjev, I. N. Sharonova, I. B. Walsh, and H. L. Haas, "Histamine potentiates N-methyl-D-aspartate responses in acutely isolated hippocampal neurons," Neuron, vol. 11, no. 5, pp. 837-844, 1993.

[66] R. E. Brown, N. B. Fedorov, H. I. Haas, and K. G. Reyman, "Histaminergic modulation of synaptic plasticity in area CA1 of rat hippocampal slices," Neuropharmacology, vol. 34, no. 2, pp. 181-190, 1995.

[67] G. W. Payne and R. S. Neuman, "Effects of hypomagnesia on histamine $\mathrm{H}_{1}$ receptor-mediated facilitation of NMDA responses," British Journal of Pharmacology, vol. 121, no. 2, pp. 199-204, 1997.

[68] H. Dai, K. Kaneko, H. Kato et al., "Selective cognitive dysfunction in mice lacking histamine $\mathrm{H}_{1}$ and $\mathrm{H}_{2}$ receptors," Neuroscience Research, vol. 57, no. 2, pp. 306-313, 2007.

[69] U. Frey, Y. Y. Huang, and E. R. Kandel, "Effects of cAMP simulate a late stage of LTP in hippocampal CA1 neurons," Science, vol. 260, no. 5114, pp. 1661-1664, 1993. 
[70] M. G. Weisskopf, P. E. Castillo, R. A. Zalutsky, and R. A. Nicoll, "Mediation of hippocampal mossy fiber long-term potentiation by cyclic AMP," Science, vol. 265, no. 5180, pp. 1878-1882, 1994.

[71] H. L. Haas, "Histamine potentiates neuronal excitation by blocking a calcium-dependent potassium conductance," Agents and Actions, vol. 14, no. 3-4, pp. 534-537, 1984.

[72] I. M. Raman, G. Tong, and C. E. Jahr, " $\beta$-Adrenergic regulation of synaptic NMDA receptors by cAMP-dependent protein kinase," Neuron, vol. 16, no. 2, pp. 415-421, 1996.

[73] N. Doreulee, Y. Yanovsky, I. Flagmeyer, D. R. Stevens, H. L. Haas, and R. E. Brown, "Histamine $\mathrm{H}_{3}$ receptors depress synaptic transmission in the corticostriatal pathway," Neuropharmacology, vol. 40, no. 1, pp. 106-113, 2001.

[74] R. E. Brown and K. G. Reymann, "Histamine $\mathrm{H}_{3}$ receptormediated depression of synaptic transmission in the dentate gyrus of the rat in vitro," The Journal of Physiology, vol. 496, no. 1, pp. 175-184, 1996.

[75] Y. Yanovsky and H. L. Haas, "Histamine increases the bursting activity of pyramidal cells in the CA3 region of mouse hippocampus," Neuroscience Letters, vol. 240, no. 2, pp. 110-112, 1998.

[76] T. V. Bliss and G. L. Collingridge, "A synaptic model of memory: long-term potentiation in the hippocampus," Nature, vol. 361, no. 6407, pp. 31-39, 1993.

[77] L. S. Xu, Y. Y. Fan, P. He, W. P. Zhang, W. W. Hu, and Z. Chen, "Ameliorative effects of histamine on spatial memory deficits induced by scopolamine infusion into bilateral dorsal or ventral hippocampus as evaluated by the radial arm maze task," Clinical and Experimental Pharmacology \& Physiology, vol. 36, no. 8, pp. 816-821, 2009.

[78] Y. W. Huang, Z. Chen, W. W. Hu et al., "Facilitating effect of histamine on spatial memory deficits induced by dizocilpine as evaluated by 8 -arm radial maze in SD rats," Acta Pharmacologica Sinica, vol. 24, no. 12, pp. 1270-1276, 2003.

[79] R. Galici, J. D. Boggs, L. Aluisio et al., "JNJ-10181457, a selective non-imidazole histamine $\mathrm{H}_{3}$ receptor antagonist, normalizes acetylcholine neurotransmission and has efficacy in translational rat models of cognition," Neuropharmacology, vol. 56, no. 8, pp. 1131-1137, 2009.

[80] Y. Yamamoto, A. Mikami, Y. Fujii, and C. Kamei, "Effect of histamine on muscimol-induced working memory deficits in radial maze performance," Journal of Pharmacological Sciences, vol. 104, no. 3, pp. 252-257, 2007.

[81] V. Pascoli, C. Boer-Saccomani, and J. F. Hermant, " $\mathrm{H}_{3}$ receptor antagonists reverse delay-dependent deficits in novel object discrimination by enhancing retrieval," Psychopharmacology, vol. 202, no. 1-3, pp. 141-152, 2009.

[82] X. Ligneau, D. Perrin, L. Landais et al., "BF2.649 [1-3-[3-(4Chlorophenyl)propoxy]propylpiperidine, hydrochloride], a nonimidazole inverse agonist/antagonist at the human histamine $\mathrm{H}_{3}$ receptor: preclinical pharmacology," The Journal of Pharmacology and Experimental Therapeutics, vol. 320, no. 1, pp. 365-375, 2007.

[83] S. Bertoni, V. Ballabeni, L. Flammini et al., "In vitro and in vivo pharmacological analysis of imidazole-free histamine $\mathrm{H}_{3}$ receptor antagonists: promising results for a brain-penetrating $\mathrm{H}_{3}$ blocker with weak anticholinesterase activity," Naunyn-Schmiedeberg's Archives of Pharmacology, vol. 378, no. 3, pp. 335-343, 2008.

[84] A. D. Medhurst, M. A. Briggs, G. Bruton et al., "Structurally novel histamine $\mathrm{H}_{3}$ receptor antagonists GSK207040 and
GSK334429 improve scopolamine-induced memory impairment and capsaicin-induced secondary allodynia in rats," Biochemical Pharmacology, vol. 73, no. 8, pp. 1182-1194, 2007.

[85] P. Bernaerts, Y. Lamberty, and E. Tirelli, "Histamine $\mathrm{H}_{3}$ antagonist thioperamide dose-dependently enhances memory consolidation and reverses amnesia induced by dizocilpine or scopolamine in a one-trial inhibitory avoidance task in mice," Behavioural Brain Research, vol. 154, no. 1, pp. 211-219, 2004.

[86] S. Miyazaki, K. Onodera, M. Imaizumi, and H. Timmerman, "Effects of clobenpropit (VUF-9153), a histamine $\mathrm{H}_{3}$ receptor antagonist, on learning and memory, and on cholinergic and monoaminergic systems in mice," Life Sciences, vol. 61, no. 4, pp. 355-361, 1997.

[87] S. Miyazaki, M. Imaizumi, and K. Onodera, "Effects of thioperamide on the cholinergic system and the step-through passive avoidance test in mice," Methods and Findings in Experimental and Clinical Pharmacology, vol. 17, no. 10, pp. 653-658, 1995.

[88] S. Miyazaki, M. Imaizumi, and K. Onodera, "Ameliorating effects of histidine on learning deficits in an elevated plusmaze test in mice and the contribution of cholinergic neuronal systems," Methods and Findings in Experimental and Clinical Pharmacology, vol. 17, pp. 57-63, 1995.

[89] S. Miyazaki, M. Imaizumi, and K. Onodera, "Effects of thioperamide, a histamine $\mathrm{H}_{3}$-receptor antagonist, on a scopolamine-induced learning deficit using an elevated plusmaze test in mice," Life Sciences, vol. 57, no. 23, pp. 21372144, 1995.

[90] K. Onodera, S. Miyazaki, and M. Imaizumi, "Cognitive involvement by negative modulation of histamine $\mathrm{H}_{2}$ receptors in passive avoidance task in mice," Methods and Findings in Experimental and Clinical Pharmacology, vol. 20, no. 4, pp. 307-310, 1998.

[91] K. Onodera, S. Miyazaki, M. Imaizumi, H. Stark, and W. Schunack, "Improvement by FUB 181, a novel histamine $\mathrm{H}_{3}$ receptor antagonist, of learning and memory in the elevated plus-maze test in mice," Naunyn-Schmiedeberg's Archives of Pharmacology, vol. 357, no. 5, pp. 508-513, 1998.

[92] G. B. Fox, J. B. Pan, T. A. Esbenshade et al., "Effects of histamine $\mathrm{H}_{3}$ receptor ligands GT-2331 and ciproxifan in a repeated acquisition avoidance response in the spontaneously hypertensive rat pup," Behavioural Brain Research, vol. 131, no. 1-2, pp. 151-161, 2002.

[93] G. B. Fox, J. B. Pan, R. J. Radek et al., "Two novel and selective nonimidazole $\mathrm{H}_{3}$ receptor antagonists A-304121 and A-317920: II. In vivo behavioral and neurophysiological characterization," The Journal of Pharmacology and Experimental Therapeutics, vol. 305, no. 3, pp. 897-908, 2003.

[94] G. B. Fox, T. A. Esbenshade, J. B. Pan et al., "Pharmacological properties of ABT-239 [4-(2-2-[(2R)-2-methylpyrrolidinyl] ethyl-benzofuran-5-yl)benzonitrile]: II. Neurophysiological characterization and broad preclinical efficacy in cognition and schizophrenia of a potent and selective histamine $\mathrm{H}_{3}$ receptor antagonist," The Journal of Pharmacology and Experimental Therapeutics, vol. 313, no. 1, pp. 176-190, 2005.

[95] K. Meguro, K. Yanai, N. Sakai et al., "Effects of thioperamide, a histamine $\mathrm{H}_{3}$ antagonist, on the step-through passive avoidance response and histidine decarboxylase activity in senescence-accelerated mice," Pharmacology Biochemistry and Behavior, vol. 50, no. 3, pp. 321-325, 1995.

[96] P. Blandina, M. Giorgetti, L. Bartolini et al., "Inhibition of cortical acetylcholine release and cognitive performance by 
histamine $\mathrm{H}_{3}$ receptor activation in rats," British Journal of Pharmacology, vol. 119, no. 8, pp. 1656-1664, 1996.

[97] C. Kamei, Y. H. Chung, and K. Tasaka, "Influence of certain $\mathrm{H}_{1}$-blockers on the step-through active avoidance response in rats," Psychopharmacology, vol. 102, no. 3, pp. 312-318, 1990.

[98] C. Frisch, R. U. Hasenohrl, and J. P. Huston, "The histamine $\mathrm{H}_{1}$-antagonist chlorpheniramine facilitates learning in aged rats," Neuroscience Letters, vol. 229, no. 2, pp. 89-92, 1997.

[99] S. Rubio, A. Begega, L. J. Santin, and J. L. Arias, "Improvement of spatial memory by (R)- $\alpha$-methylhistamine, a histamine $\mathrm{H}_{3}$-receptor agonist, on the Morris water-maze in rat," Behavioural Brain Research, vol. 129, no. 1-2, pp. 77-82, 2002.

[100] M. G. Lee, J. J. Chrobak, A. Sik, R. G. Wiley, and G. Buzsaki, "Hippocampal theta activity following selective lesion of the septal cholinergic system," Neuroscience, vol. 62, no. 4, pp. 1033-1047, 1994.

[101] M. H. Bassant, E. Apartis, F. R. Jazat-Poindessous, R. G. Wiley, and Y. A. Lamour, "Selective immunolesion of the basal forebrain cholinergic neurons: effects on hippocampal activity during sleep and wakefulness in the rat," Neurodegeneration, vol. 4, no. 1, pp. 61-70, 1995.

[102] C. Xu, K. A. Michelsen, M. Wu, E. Morozova, P. Panula, and M. Alreja, "Histamine innervation and activation of septohippocampal GABAergic neurons: involvement of local ACh release," The Journal of Physiology, vol. 561, no. 3, pp. 657-670, 2004.

[103] T. Mochizuki, K. Okakura-Mochizuki, A. Horii, Y. Yamamoto, and A. Yamatodani, "Histaminergic modulation of hippocampal acetylcholine release in vivo," Journal of Neurochemistry, vol. 62, no. 6, pp. 2275-2282, 1994

[104] L. Bacciottini, M. B. Passani, L. Giovannelli et al., "Endogenous histamine in the medial septum-diagonal band complex increases the release of acetylcholine from the hippocampus: a dual-probe microdialysis study in the freely moving rat," The European Journal of Neuroscience, vol. 15, no. 10, pp. 1669-1680, 2002.

[105] R. Leurs, R. A. Bakker, H. Timmerman, and I. J. De Esch, "The histamine $\mathrm{H}_{3}$ receptor: from gene cloning to $\mathrm{H}_{3}$ receptor drugs," Nature Reviews Drug Discovery, vol. 4, no. 2, pp. 107-120, 2005.

[106] A. Terao, T. L. Steininger, S. R. Morairty, and T. S. Kilduff, "Age-related changes in histamine receptor mRNA levels in the mouse brain," Neuroscience Letters, vol. 355, no. 1-2, pp. 81-84, 2004.

[107] C. J. E. Niemegeers, F. H. L. Awouters, and P. A. J. Janssen, "The in vivo pharmacological profile of histamine $\left(\mathrm{H}_{1}\right)$ antagonists in the rat," Drug Development Research, vol. 2, no. 6, pp. 559-566, 1982.

[108] A. Carlsson and M. Lindqvist, "Central and peripheral monoaminergic membrane-pump blockade by some addictive analgesics and antihistamines," The Journal of Pharmacy and Pharmacology, vol. 21, no. 7, pp. 460-464, 1969.

[109] N. Granado, O. Ortiz, L. M. Suarez et al., " $D_{1}$ but not $D_{5}$ dopamine receptors are critical for LTP, spatial learning, and LTP-induced arc and zif268 expression in the hippocampus," Cerebral Cortex, vol. 18, no. 1, pp. 1-12, 2008.

[110] A. Mura and J. Feldon, "Spatial learning in rats is impaired after degeneration of the nigrostriatal dopaminergic system," Movement Disorders, vol. 18, no. 8, pp. 860-871, 2003.

[111] S. F. Acevedo, T. Pfankuch, H. Ohtsu, and J. Raber, "Anxiety and cognition in female histidine decarboxylase knockout $\left(\mathrm{Hdc}^{-/-}\right)$mice," Behavioural Brain Research, vol. 168, no. 1, pp. 92-99, 2006.
[112] E. Dere, M. A. De Souza-Silva, B. Topic, R. E. Spieler, H. L. Haas, and J. P. Huston, "Histidine-decarboxylase knockout mice show deficient nonreinforced episodic object memory, improved negatively reinforced water-maze performance, and increased neo- and ventro-striatal dopamine turnover," Learning and Memory, vol. 10, no. 6, pp. 510-519, 2003.

[113] L. Liu, S. Zhang, Y. Zhu et al., "Improved learning and memory of contextual fear conditioning and hippocampal CA1 long-term potentiation in histidine decarboxylase knock-out mice," Hippocampus, vol. 17, no. 8, pp. 634-641, 2007.

[114] E. Dere, M. A. De Souza-Silva, R. E. Spieler et al., "Changes in motoric, exploratory and emotional behaviours and neuronal acetylcholine content and 5-HT turnover in histidine decarboxylase-KO mice," The European Journal of Neuroscience, vol. 20, no. 4, pp. 1051-1058, 2004.

[115] K. Yanai, L. Z. Son, M. Endou et al., "Behavioural characterization and amounts of brain monoamines and their metabolites in mice lacking histamine $\mathrm{H}_{1}$ receptors," Neuroscience, vol. 87, no. 2, pp. 479-487, 1998.

[116] A. Zlomuzica, D. Viggiano, M. A. De Souza Silva et al., "The histamine $\mathrm{H}_{1}$-receptor mediates the motivational effects of novelty," The European Journal of Neuroscience, vol. 27, no. 6, pp. 1461-1474, 2008.

[117] A. Zlomuzica, L. A. Ruocco, A. G. Sadile, J. P. Huston, and E. Dere, "Histamine $\mathrm{H}_{1}$ receptor knockout mice exhibit impaired spatial memory in the eight-arm radial maze," British Journal of Pharmacology, vol. 157, no. 1, pp. 86-91, 2009.

[118] A. Rizk, J. Curley, J. Robertson, and J. Raber, "Anxiety and cognition in histamine $\mathrm{H}_{3}$ receptor $^{-/-}$mice," The European Journal of Neuroscience, vol. 19, no. 7, pp. 1992-1996, 2004.

[119] E. Dere, A. Zlomuzica, D. Viggiano et al., "Episodic-like and procedural memory impairments in histamine $\mathrm{H}_{1}$ Receptor knockout mice coincide with changes in acetylcholine esterase activity in the hippocampus and dopamine turnover in the cerebellum," Neuroscience, vol. 157, no. 3, pp. 532-541, 2008.

[120] M. A. De Almeida and I. Izquierdo, "Memory facilitation by histamine," Archives Internationales de Pharmacodynamie et de Therapie, vol. 283, no. 2, pp. 193-198, 1986.

[121] M. A. De Almeida and I. Izquierdo, "Intracerebroventricular histamine, but not $48 / 80$, causes posttraining memory facilitation in the rat," Archives Internationales de Pharmacodynamie et de Therapie, vol. 291, no. 1, pp. 202-207, 1988.

[122] M. R. Zarrindast, R. Ahmadi, S. Oryan, K. Parivar, and A. Haeri-Rohani, "Effects of $\alpha$-adrenoceptor agonists and antagonists on histamine-induced impairment of memory retention of passive avoidance learning in rats," European Journal of Pharmacology, vol. 454, no. 2-3, pp. 193-198, 2002.

[123] M. Eidi, M. R. Zarrindast, A. Eidi, S. Oryan, and K. Parivar, "Effects of histamine and cholinergic systems on memory retention of passive avoidance learning in rats," European Journal of Pharmacology, vol. 465, no. 1-2, pp. 91-96, 2003.

[124] M. R. Zarrindast, M. Eidi, A. Eidi, and S. Oryan, "Effects of histamine and opioid systems on memory retention of passive avoidance learning in rats," European Journal of Pharmacology, vol. 452, no. 2, pp. 193-197, 2002.

[125] M. R. Zarrindast, L. Parsaei, and S. Ahmadi, "Repeated administration of histamine improves memory retrieval of inhibitory avoidance by lithium in mice," Pharmacology, vol. 81, no. 2, pp. 187-194, 2008.

[126] C. Kamei, Y. Okumura, and K. Tasaka, "Influence of histamine depletion on learning and memory recollection in rats," Psychopharmacology, vol. 111, no. 3, pp. 376-382, 1993. 
[127] K. Tasaka, C. Kamei, H. Akahori, and K. Kitazumi, "The effects of histamine and some related compounds on conditioned avoidance response in rats," Life Sciences, vol. 37, no. 21, pp. 2005-2014, 1985.

[128] C. Kamei, Z. Chen, S. Nakamura, and Y. Sugimoto, "Effects of intracerebroventricular injection of histamine on memory deficits induced by hippocampal lesions in rats," Methods and Findings in Experimental and Clinical Pharmacology, vol. 19, no. 4, pp. 253-259, 1997.

[129] H. Prast, A. Argyriou, and A. Philippu, "Histaminergic neurons facilitate social memory in rats," Brain Research, vol. 734, no. 1-2, pp. 316-318, 1996.

[130] M. Nishiga and C. Kamei, "Ameliorative effects of histamine on 7-chlorokynurenic acid-induced spatial memory deficits in rats," Psychopharmacology, vol. 166, no. 4, pp. 360-365, 2003.

[131] Z. Chen, Y. Sugimoto, and C. Kamei, "Effects of intracerebroventricular injection of alpha-fluoromethylhistidine on radial maze performance in rats," Pharmacology Biochemistry and Behavior, vol. 64, no. 3, pp. 513-518, 1999.

[132] C. Kamei and K. Tasaka, "Participation of histamine in the step-through active avoidance response and its inhibition by $\mathrm{H}_{1}$-blockers," Japanese Journal of Pharmacology, vol. 57, no. 4, pp. 473-482, 1991.

[133] P. Malmberg-Aiello, A. Ipponi, P. Blandina, L. Bartolini, and W. Schunack, "Pro-cognitive effect of a selective histamine $\mathrm{H}_{1}$-receptor agonist, 2-(3-trifluoromethylphenyl)histamine, in the rat object recognition test," Inflammation Research, vol. 52, supplement 1, pp. S33-S34, 2003.

[134] R. U. Hasenohrl, K. Weth, and J. P. Huston, "Intraventricular infusion of the histamine $\mathrm{H}_{1}$ receptor antagonist chlorpheniramine improves maze performance and has anxiolytic-like effects in aged hybrid Fischer 344XBrown Norway rats," Experimental Brain Research, vol. 128, no. 4, pp. 435-440, 1999.

[135] C. Kamei and K. Tasaka, "Effect of histamine on memory retrieval in old rats," Biological and Pharmaceutical Bulletin, vol. 16, no. 2, pp. 128-132, 1993.

[136] A. Kishi, M. Ohno, and S. Watanabe, "Concurrent activation of hippocampal glycine and polyamine sites of the $\mathrm{N}$ methyl-D-aspartate receptor synergistically reverses working memory deficits in rats," Neuroscience Letters, vol. 257, no. 3, pp. 131-134, 1998.

[137] R. S. Ross and S. D. Slotnick, "The hippocampus is preferentially associated with memory for spatial context," Journal of Cognitive Neuroscience, vol. 20, no. 3, pp. 432-446, 2008.

[138] J. P. Aggleton and M. W. Brown, "Contrasting hippocampal and perirhinal cortex function using immediate early gene imaging," Quarterly Journal of Experimental Psychology Section B, vol. 58, no. 3-4, pp. 218-233, 2005.

[139] M. J. Eacott and E. A. Gaffan, "The roles of perirhinal cortex, postrhinal cortex, and the fornix in memory for objects, contexts, and events in the rat," Quarterly Journal of Experimental Psychology Section B, vol. 58, no. 3-4, pp. 202217, 2005.

[140] W. C. Da Silva, J. S. Bonini, L. R. Bevilaqua, I. Izquierdo, and M. Cammarota, "Histamine enhances inhibitory avoidance memory consolidation through a $\mathrm{H}_{2}$ receptor-dependent mechanism," Neurobiology of Learning and Memory, vol. 86, no. 1, pp. 100-106, 2006.

[141] E. O. Alvarez and A. M. Banzan, "Hippocampal histamine receptors: possible role on the mechanisms of memory in the rat, II," Journal of Neural Transmission, vol. 103, no. 1-2, pp. 147-156, 1996.
[142] E. O. Alvarez and A. M. Banzan, "The activation of histamine-sensitive sites of the ventral hippocampus modulates the consolidation of a learned active avoidance response in rats," Behavioural Brain Research, vol. 189, no. 1, pp. 9299, 2008.

[143] E. O. Alvarez, M. B. Ruarte, and A. M. Banzan, "Histaminergic systems of the limbic complex on learning and motivation," Behavioural Brain Research, vol. 124, no. 2, pp. 195-202, 2001.

[144] C. Yu, Y. Shen, L. Xu et al., "Effect of endogenous histamine in the ventral hippocampus on fear memory deficits induced by scopolamine as evaluated by step-through avoidance response in rats," Physiology and Behavior, vol. 87, no. 4, pp. 687-693, 2006.

[145] M. G. Giovannini, M. Efoudebe, M. B. Passani et al., "Improvement in fear memory by histamine-elicited ERK2 activation in hippocampal CA3 cells," The Journal of Neuroscience, vol. 23, no. 27, pp. 9016-9023, 2003.

[146] Y. W. Huang, W. W. Hu, Z. Chen et al., "Effect of the histamine $\mathrm{H}_{3}$-antagonist clobenpropit on spatial memory deficits induced by MK-801 as evaluated by radial maze in Sprague-Dawley rats," Behavioural Brain Research, vol. 151, no. 1-2, pp. 287-293, 2004.

[147] E. Nakazato, T. Yamamoto, M. Ohno, and S. Watanabe, "Cholinergic and glutamatergic activation reverses working memory failure by hippocampal histamine $\mathrm{H}_{1}$ receptor blockade in rats," Life Sciences, vol. 67, no. 10, pp. 1139-1147, 2000.

[148] D. Amaral and P. Lavenex, "Hippocampal neuroanatomy," in The Hippocampus Book, P. Andersen, D. Amaral, T. Bliss, and J. O'Keefe, Eds., Oxford University Press, New York, NY, USA, 2006.

[149] D. G. Amaral and M. P. Witter, "Hippocampal formation," in The Rat Nervous System, G. Paxinos, Ed., Academic Press, New York, NY, USA, 1995.

[150] M. S. Fanselow and H. W. Dong, "Are the dorsal and ventral hippocampus functionally distinct structures?" Neuron, vol. 65, no. 1, pp. 7-19, 2010.

[151] M. Pitkanen, J. Sirvio, A. Ylinen, E. Koivisto, and P. Riekkinen Sr., "Effects of NMDA receptor modulation hippocampal type 2 theta activity in rats," General Pharmacology, vol. 26, no. 5, pp. 1065-1070, 1995.

[152] R. G. Phillips and J. E. LeDoux, "Differential contribution of amygdala and hippocampus to cued and contextual fear conditioning," Behavioral Neuroscience, vol. 106, no. 2, pp. 274-285, 1992.

[153] H. L. Haas, O. A. Sergeeva, and O. Selbach, "Histamine in the nervous system," Physiological Reviews, vol. 88, no. 3, pp. 1183-1241, 2008.

[154] M. B. Passani, I. Cangioli, E. Baldi, C. Bucherelli, P. F. Mannaioni, and P. Blandina, "Histamine $\mathrm{H}_{3}$ receptormediated impairment of contextual fear conditioning and in-vivo inhibition of cholinergic transmission in the rat basolateral amygdala," The European Journal of Neuroscience, vol. 14, no. 9, pp. 1522-1532, 2001.

[155] P. Blandina, M. Efoudebe, G. Cenni, P. Mannaioni, and M. B. Passani, "Acetylcholine, histamine, and cognition: two sides of the same coin," Learning and Memory, vol. 11, no. 1, pp. $1-8,2004$.

[156] E. Baldi, C. Bucherelli, W. Schunack, G. Cenni, P. Blandina, and M. B. Passani, "The $\mathrm{H}_{3}$ receptor protean agonist proxyfan enhances the expression of fear memory in the rat," Neuropharmacology, vol. 48, no. 2, pp. 246-251, 2005. 
[157] I. Ehrlich, Y. Humeau, F. Grenier, S. Ciocchi, C. Herry, and A. Luthi, "Amygdala inhibitory circuits and the control of fear memory," Neuron, vol. 62, no. 6, pp. 757-771, 2009.

[158] J. E. LeDoux, "Emotion circuits in the brain," Annual Review of Neuroscience, vol. 23, pp. 155-184, 2000.

[159] S. Maren, "Nuerobiology of Pavlovian fear conditioning," Annual Review of Neuroscience, vol. 24, pp. 897-931, 2001.

[160] J. L. McGaugh, "The amygdala modulates the consolidation of memories of emotionally arousing experiences," Annual Review of Neuroscience, vol. 27, pp. 1-28, 2004.

[161] X. Jiang, A. Chen, and H. Li, "Histaminergic modulation of excitatory synaptic transmission in the rat basolateral amygdala," Neuroscience, vol. 131, no. 3, pp. 691-703, 2005. 

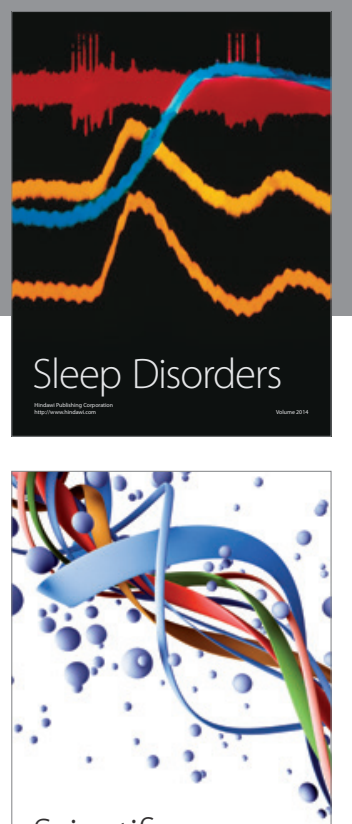

Scientifica
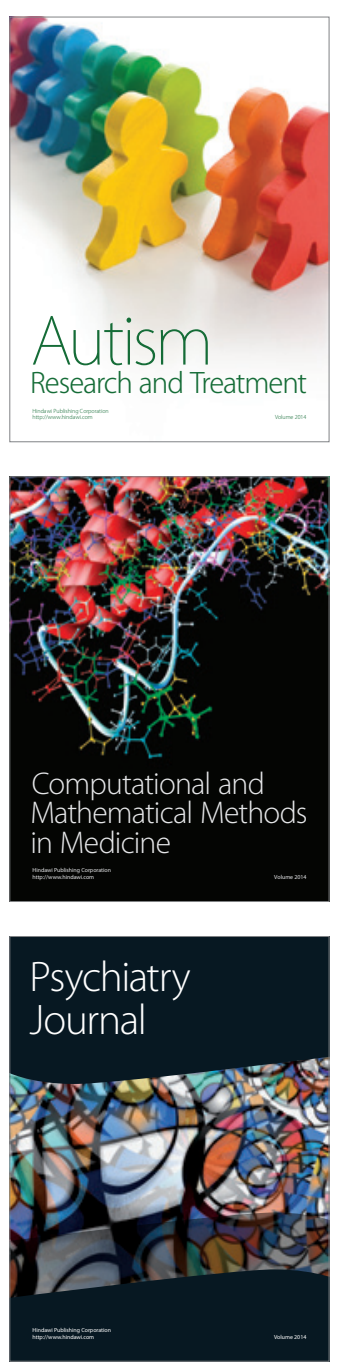
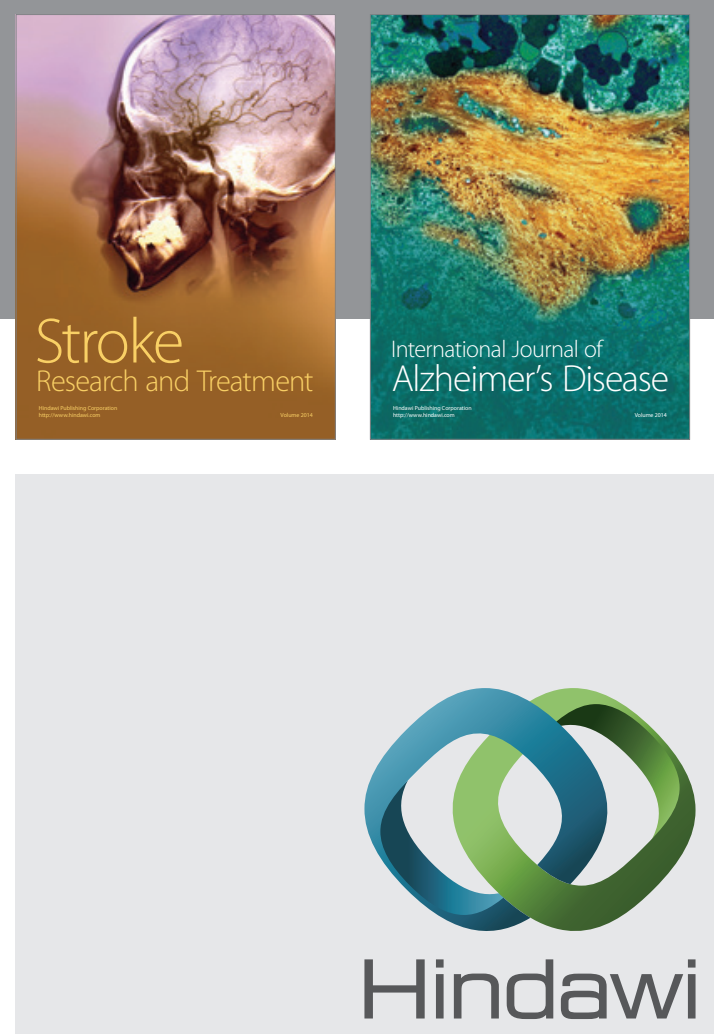

Submit your manuscripts at

http://www.hindawi.com
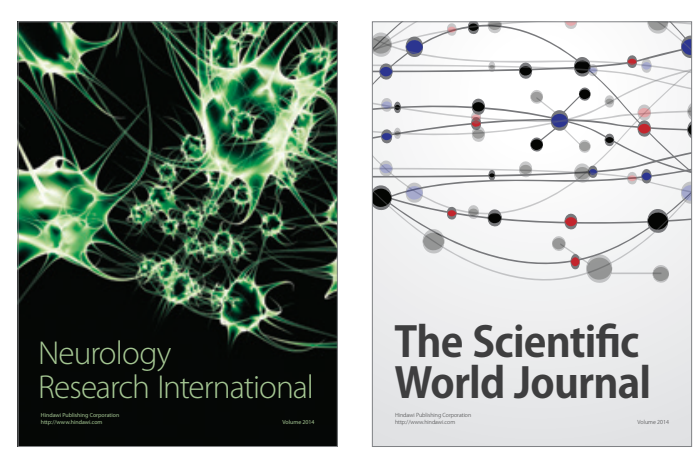

The Scientific World Journal

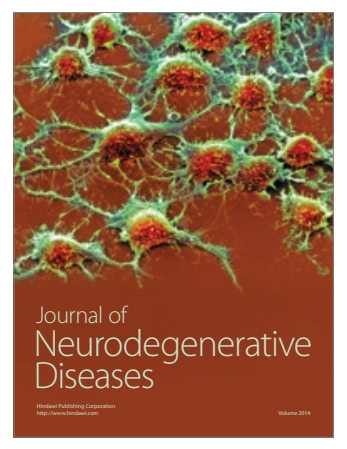

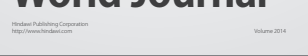

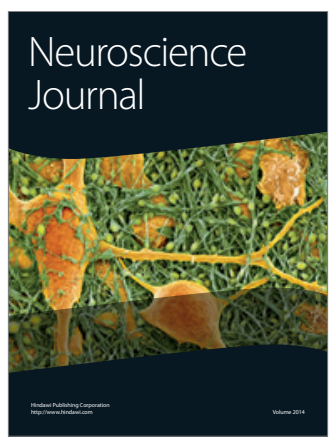

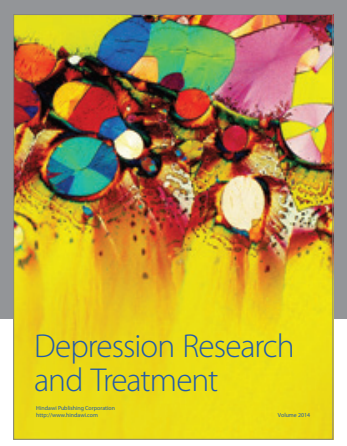
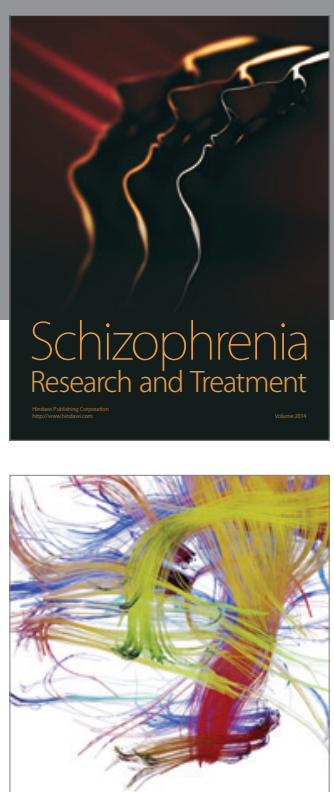

Brain Science

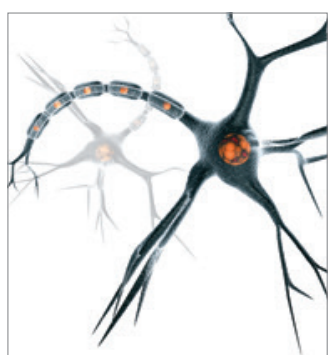

Neural Plasticity
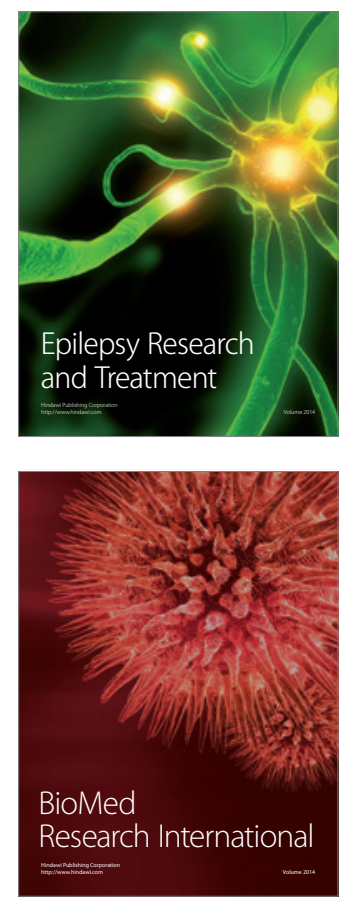

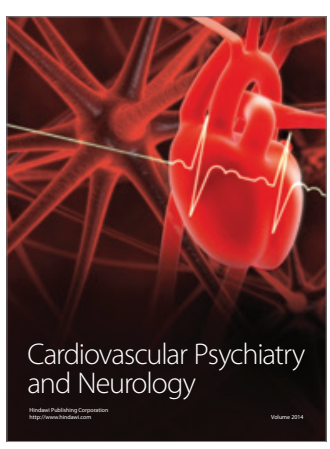

Parkinson's

Disease
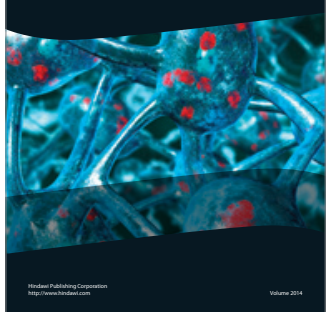